\title{
36. CRETACEOUS-PALEOGENE BIOMAGNETOSTRATIGRAPHY OF SITES 752-755, BROKEN RIDGE: A SYNTHESIS ${ }^{1}$
}

\author{
James J. Pospichal, ${ }_{8}^{2}$ Jonathan Dehn, ${ }^{3}$ Neal W. Driscoll, ${ }^{4}$ A.J.M. van Eijden, ${ }^{5}$ John W. Farrell, ${ }^{6}$ Elisabeth Fourtanier, \\ Paul Gamson, ${ }^{8}$ Jeff Gee, ${ }^{9}$ Thomas R. Janecek,${ }^{10}$ D. Graham Jenkins, ${ }^{8}$ Chris Klootwijk, ${ }^{11}$ Ritsuo Nomura, ${ }^{12}$ \\ Robert M. Owen, ${ }^{13}$ David K. Rea, ${ }^{13}$ Purtyasti Resiwati, ${ }^{14}$ Jan Smit, ${ }^{5}$ and Guy Smith ${ }^{15}$
}

\begin{abstract}
Broken Ridge, in the eastern Indian Ocean, is a shallow-water volcanic platform which formed during the Early to middle Cretaceous at which time it comprised the northern portion of the Kerguelen-Heard Plateau. Rifting during the middle Eocene and subsequent seafloor spreading has moved Broken Ridge about $20^{\circ} \mathrm{N}$ to its present location. The sedimentary section of Broken Ridge includes Turonian-lower Eocene limestone and chalk with volcanic ash, an interval of detrital sands and gravels associated with middle Eocene rifting and uplift, and a middle-late Oligocene unconformity overlain by a thin section of Neogene-Holocene pelagic calcareous ooze. This paper summarizes the available post-cruise biostratigraphic and magnetostratigraphic data for the CretaceousPaleogene section on Broken Ridge. The synthesis of this information permits a more precise interpretation of the timing of events in the history of Broken Ridge, in particular the timing and duration of the middle Eocene rifting event. Paleontologic data support rapid flexural uplift of Broken Ridge in response to mechanical rather than thermal forces. Other highlights of the section include a complete Cretaceous/Tertiary boundary and an opportunity for first-order correlation of Paleogene diatom stratigraphy with that of the calcareous groups.
\end{abstract}

\section{INTRODUCTION}

As a part of Ocean Drilling Program (ODP) Leg 121 objectives, drilling took place at four closely-spaced sites (752-755) on Broken Ridge in the eastern Indian Ocean (Fig. 1, Table 1) in order to test hypotheses of rifting mechanisms and to recover a Cretaceous-Holocene carbonate sequence for paleoceanographic study. Broken Ridge is a rather shallow $(\sim 1100 \mathrm{~m})$ east-trending platform which formed as the northern portion of the KerguelenHeard Plateau, probably by intraplate volcanism during the Early to middle Cretaceous. In the region of Broken Ridge, carbonate sediments accumulated on the slowly subsiding plateau along with a gradually decreasing supply of volcanic ash through the

${ }^{1}$ Weissel, J., Peirce, J., Taylor, E., Alt, J., et al., 1991. Proc. ODP, Sci. Results, 121: College Station, TX (Ocean Drilling Program).

${ }^{2}$ Department of Geology, Florida State University, Tallahassee, FL 32306, U.S.A.

${ }_{3}^{3}$ Institut für Mineralogie, Ruhr-Universität Bochum, Bochum, Federal Republic of Germany.

${ }^{4}$ Lamont-Doherty Geological Observatory, Palisades, NY 10964, U.S.A.

${ }_{5}^{5}$ Geomarine Center, Institute for Earth Sciences, Free University, P.O. Box 7161, 1007 MC Amsterdam, Netherlands.

${ }^{6}$ Department of Geological Sciences, Brown University, Providence, RI 02912 , U.S.A.

${ }_{7}$ Laboratoire D'Hydrologie et de Géochimie Isotopique, Bat. 504, Université Paris Sud, 91405 Orsay Cedex, France.

${ }^{8}$ Department of Earth Sciences, Open University, Milton Keynes MK7 6AA United Kingdom.

${ }^{9}$ Scripps Institution of Oceanography, La Jolla, CA 92093, U.S.A.

${ }^{10}$ Ocean Drilling Program, Texas A\&M University, College Station, TX 77845 , U.S.A.

${ }^{11}$ Bureau of Mineral Resources, Geology and Geophysics, P.O. Box 386, Canberra ACT 2601, Australia.

${ }^{12}$ Department of Earth Sciences, Faculty of Education, Shimane University, Matsue. 690, Japan.

${ }^{13}$ Department of Geological Sciences, University of Michigan, Ann Arbor, MI 48109-1063, U.S.A.

${ }^{14}$ Department of Geology, University of Nebraska, Lincoln, NE 68588-0340, U.S.A.

${ }^{5}$ Department of Earth and Atmospheric Sciences, St. Louis University, P.O. Box 8099, Laclede Station, St. Louis, MO 63156, U.S.A.
Late Cretaceous and Paleocene. In the middle Eocene (Anomaly 18 time), Broken Ridge was uplifted an estimated $2000-2500 \mathrm{~m}$ (Weissel and Karner, 1989; Rea et al., 1990) by the rifting process and the pre-rift sediments were tilted with at least a portion of the plateau exposed above wave-base (Peirce, Weissel, et al., 1989). The angular unconformity produced by this uplift is illustrated in the seismic profile of Figure 2, and changes in paleodepths estimated by benthic foraminifer assemblages are shown in Figure 3 . Shallow-water sands and gravels accumulated immediately above the northward-dipping sediments and with subsequent subsidence, a thin sequence of upper Oligocene-Holocene pelagic carbonate oozes was deposited on Broken Ridge (Fig. 2) as it moved northwest from its pre-rift position of $\sim 50^{\circ}-55^{\circ} \mathrm{S}$ latitude to its present locality. This reconstructed motion for Broken Ridge ODP Leg 121 sites and Ninetyeast Ridge ODP and DSDP sites is shown in Figure 4.

In addition to the middle Eocene unconformity brought about by uplift, a middle-late Oligocene hiatus is also present, produced either by increased bottom-current activity related to the onset of Antarctic circumpolar circulation or associated with a middle Oligocene eustatic sea-level fall (see Rea et al., 1990, for discussion).

The main objective for drilling at Sites 752-755 (Fig. 1, Table 1) on Broken Ridge was to answer questions concerning the lithospheric response to rifting. Crucial to this problem is the time frame for such events (for details of objectives, see Peirce, Weissel, et al., 1989). Thus, the immediate goal of the shipboard paleontologists and magnetostratigraphers was to date the youngest of the northward-dipping sediments below the angular unconformity (Site 753) and the oldest strata above it (Site 754), in order to constrain the timing of the rifting process. This paper summarizes these efforts and offers more precise interpretations afforded by the synthesis of the data. A list of the authors and their contributions of data to this paper is presented in Table 2. In addition, this paper presents stratigraphic data from a remarkably complete high-latitude Maestrichtian through lower Eocene section which includes a complete Cretaceous/Tertiary boundary sequence. Furthermore, diatoms which are abundant and well 


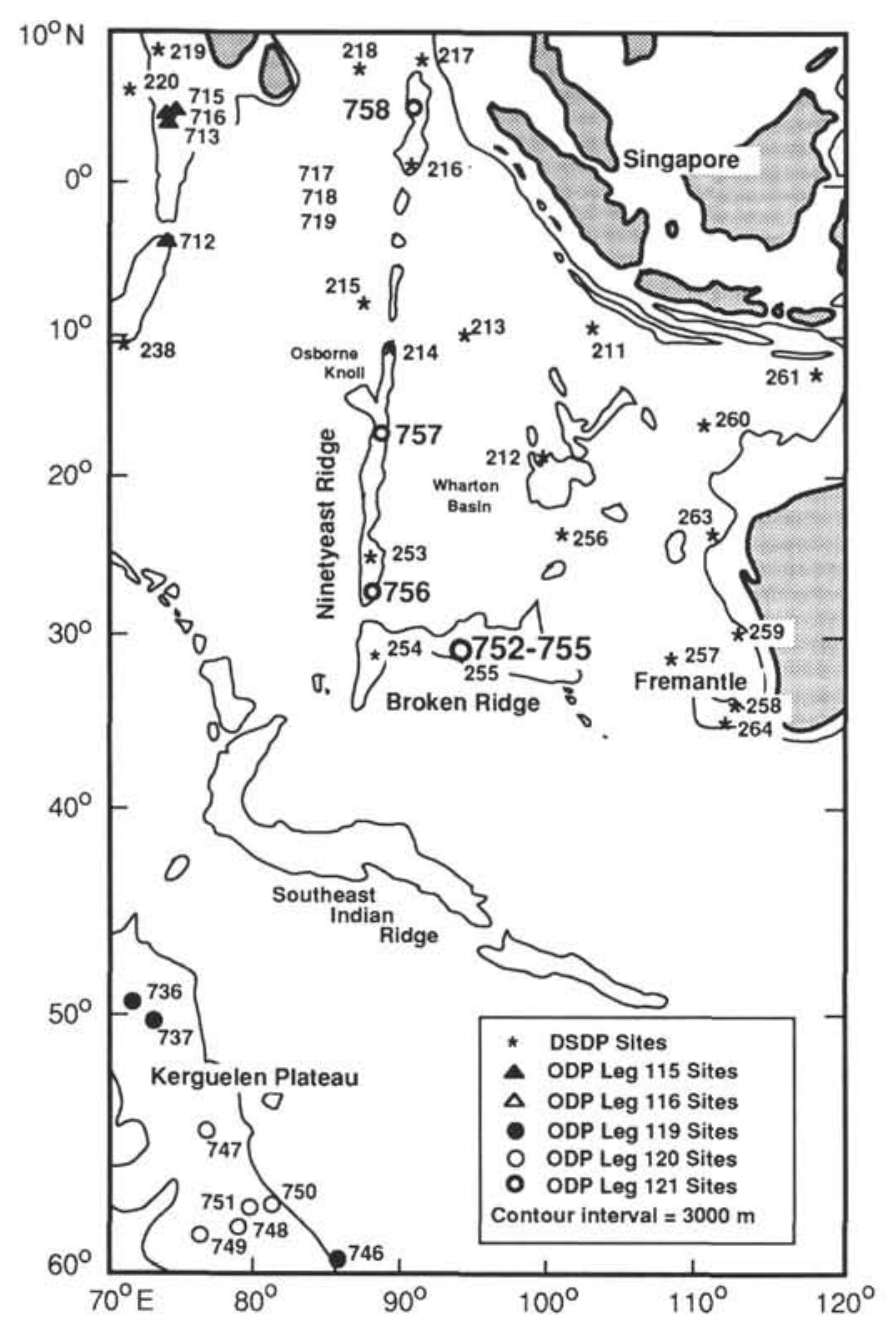

Figure 1. Map of the Indian Ocean showing the location of ODP and DSDP drill sites.

Table 1. Latitude, longitude, and water depths for Sites 752-755.

\begin{tabular}{ccccc}
\hline Site & Hole & $\begin{array}{c}\text { Latitude } \\
\text { (S) }\end{array}$ & $\begin{array}{c}\text { Longitude } \\
\text { (E) }\end{array}$ & $\begin{array}{c}\text { Water depth } \\
\text { (m) }\end{array}$ \\
\hline 752 & A & $30^{\circ} 53.475^{\prime}$ & $93^{\circ} 34.652^{\prime}$ & 1086.3 \\
752 & B & $30^{\circ} 53.483^{\prime}$ & $93^{\circ} 34.652^{\prime}$ & 1086.3 \\
753 & A & $30^{\circ} 50.340^{\prime}$ & $93^{\circ} 35.394^{\prime}$ & 1187.0 \\
754 & A & $30^{\circ} 56.439^{\prime}$ & $93^{\circ} 33.991^{\prime}$ & 1063.6 \\
754 & B & $30^{\circ} 56.439^{\prime}$ & $93^{\circ} 33.954^{\prime}$ & 1065.5 \\
755 & A & $31^{\circ} 01.786^{\prime}$ & $93^{\circ} 32.803^{\prime}$ & 1067.9 \\
\hline
\end{tabular}

preserved in the chalks of the middle to upper Paleocene and lower Eocene permit an opportunity for the correlation of the biostratigraphy of this group with that of the calcareous microfossils. These data add greatly to a recent increase in knowledge of Southern Ocean stratigraphy and provide a northern "anchor" for the studies of the southernmost sites of Kerguelen Plateau Legs 119 and 120.

The biostratigraphy and magnetostratigraphy reported here are tied to the time scales of Berggren et al. (1985) and Kent and Gradstein (1985). Lists of the nannofossil, foraminifer, diatom datum levels, and magnetic chron boundaries with corresponding absolute age assignments are given in Tables 3-8, respectively. The scheme of Okada and Bukry (1980) is used for Paleogene calcareous nannofossils (Resiwati, pers. comm.), and that of Sissingh (1977) for the Cretaceous (Resiwati, this volume). For planktonic foraminifers (van Eijden and Smit, this volume), the numbered schemes of Banner and Blow (1965) and Blow (1969) are employed for the Paleogene and the scheme of Caron (1985) for the Cretaceous. Because of the absence of some of the important marker species due to the high paleolatitude of Broken Ridge during the Cretaceous-Paleogene, it was necessary to combine many of the foraminifer zones and a few of the nannofossil zones.

Information on benthic foraminifers of Sites 752-754 is provided by Nomura (this volume). The method for paleodepth estimates is based on comparisons with van Morkhoven et al. (1986) with biostratigraphic references to Tjalsma and Lohmann (1983) and Berggren and Miller (1989).

Fourtanier (this volume) proposes a new diatom zonal scheme for the Paleocene-lower Eocene of Site 752, which is correlated with the calcareous microfossil stratigraphy.

\section{SITE 752}

(Fig. 5, Tables 3-6)

Two holes were drilled at Site 752 (Fig. 5) to a total depth of $435.6 \mathrm{mbsf}$ (meters below seafloor) where drilling was terminated in upper Maestrichtian chalk. Two lithologic units were identified (Fig. 5) (Peirce, Weissel, et al., 1989). Unit I, which includes all sediments above the angular unconformity (post-rift), is a Pleistocene to uppermost Eocene nannofossil ooze. The base of this unit is represented by the limestone and chert pebble layer, of which very little was recovered (Peirce, Weissel, et al., 1989). This layer lies directly above the tilted strata and is estimated to be about $20 \mathrm{~m}$ thick. Unit II (pre-rift), divided into three subunits of lower Eocene to upper Maestrichtian age, is predominately nannofossil and calcareous chalk with silica-rich sections (Fig. 5). Ash layers, porcellanite, and chert are common in Subunit IIC in Cores 121-752B-8R through 121-752B-13R (325.8-383.6 mbsf). The Cretaceous/Tertiary boundary is present in Section 121$752 \mathrm{~B}-11 \mathrm{R}-3$ (358.7 mbsf) at the base of a $6 \mathrm{~m}$ thick compound ash layer. Porcellanite and chert are present immediately above the boundary.

Calcareous nannofossils are abundant and moderately well preserved in the upper Paleocene-lower Eocene sediments of Site 752. In Danian samples nannofossils are few to common and preservation is variable. Preservation is poor in samples immediately above and below the Cretaceous/Tertiary boundary and some intervals are barren of nannofossils. Calcareous nannofossils are common to abundant and, for the most part, poorly to moderately preserved in Maestrichtian samples. Planktonic foraminifers are abundant and well preserved in the upper Oligocene but less abundant and poorly preserved in the lower Oligocene and in sediments of the erosional layer. Paleocene and Maestrichtian faunas are poorly preserved and samples immediately above the Cretaceous/Tertiary boundary are barren of planktonic foraminifers. Generally, benthic foraminifers are much less abundant than planktonics, and preservation is moderate to good in the Maestrichtian to lower Eocene and poor in the upper Eocene detrital layer.

Diatoms are well preserved and common in middle Paleocene to lower Eocene sediments. Preservation below Core 121-752A$31 \mathrm{X}$ is very poor and samples are barren or contain rare and unrecognizable specimens. Radiolarians are also present in all diatom bearing samples. Coral, bryozoan, and echinoderm fragments are present in lower Oligocene Core 121-11H (Peirce, Weissel, et al., 1989). 


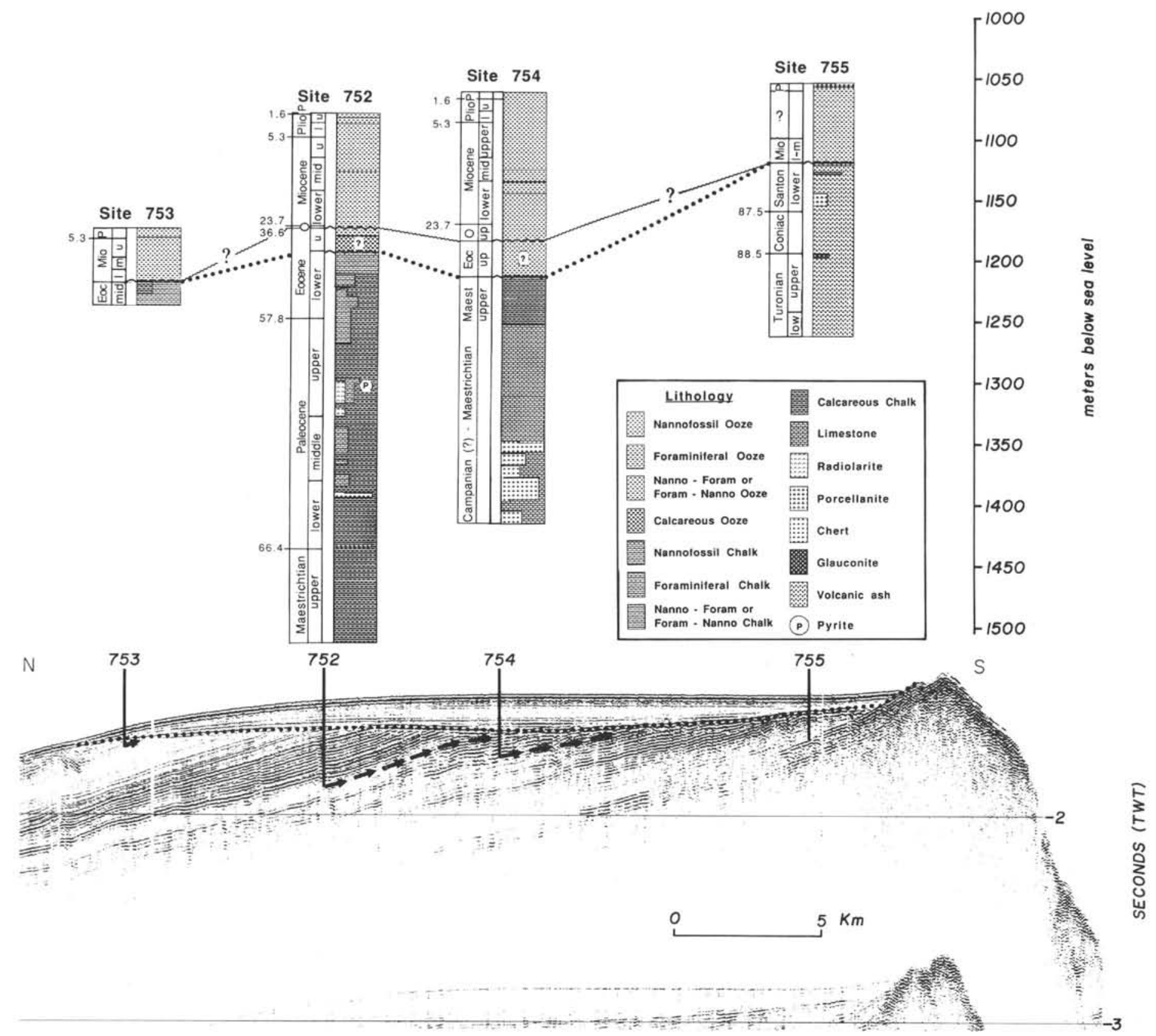




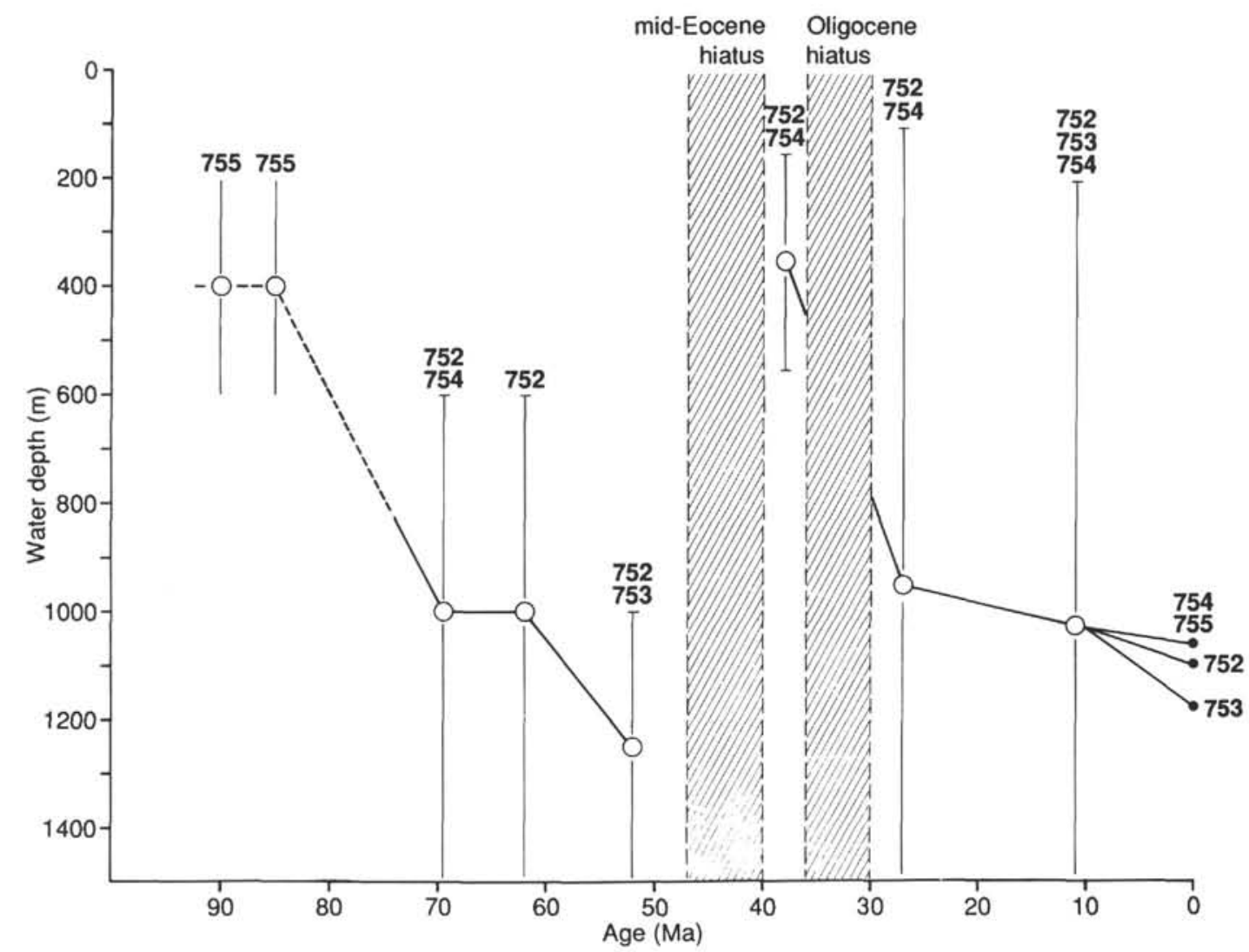

Figure 3. Estimates of paleodepth for ODP Sites 752-755, based on benthic foraminifers. The open circles denote depth estimates from the most abundant species in the sample, and the vertical lines represent the range of water-depth estimates for all of the benthic foraminifers in the sample from Peirce, Weissel, et al. (1989).

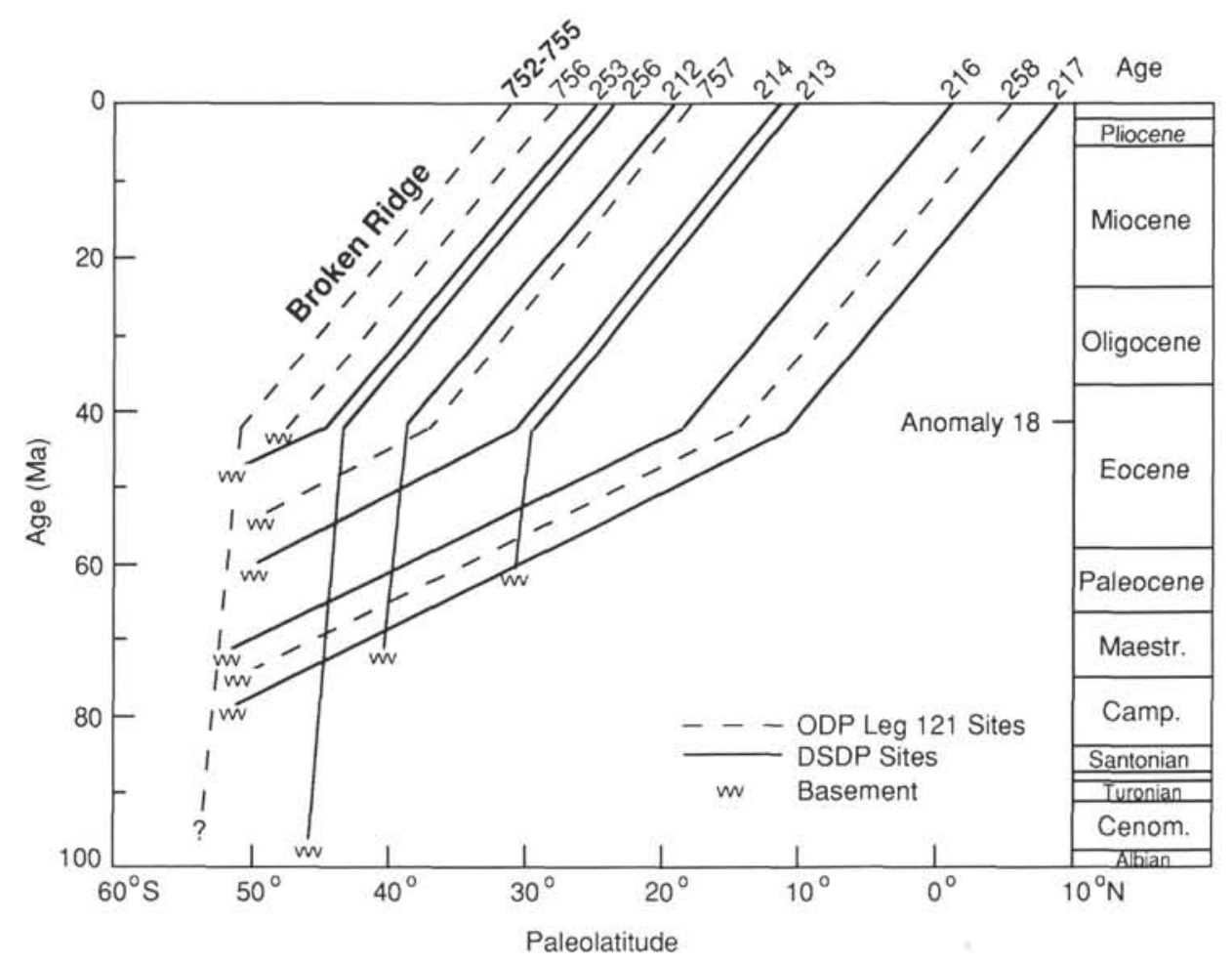

Figure 4. Predicted paleolatitudes for ODP Leg 121 sites and nearby DSDP sites, based on Peirce (1978) and Royer and Sandwell (1989) from Peirce, Weissel, et al. (1989). 
Table 2. Sources of data for this paper.

\begin{tabular}{|c|c|}
\hline Source & Contribution \\
\hline $\begin{array}{l}\text { Site chapters in Peirce, } \\
\text { Weissel, et al., } 1989\end{array}$ & $\begin{array}{l}\text { Core recovery, lithology, } \\
\text { water depths }\end{array}$ \\
\hline Gee, Klootwijk, and Smith & Magnetostratigraphy \\
\hline Jenkins and Gamson & $\begin{array}{l}\text { Neogene foraminifer stratig- } \\
\text { raphy }\end{array}$ \\
\hline van Eijden and Smit & $\begin{array}{l}\text { Cretaceous-Paleogene fora- } \\
\text { minifer stratigraphy }\end{array}$ \\
\hline Resiwati & $\begin{array}{l}\text { Cretaceous-Neogene nanno- } \\
\text { fossil stratigraphy }\end{array}$ \\
\hline Pospichal & $\begin{array}{c}\text { Cretaceous/Tertiary boundary } \\
\text { nannofossil stratigraphy }\end{array}$ \\
\hline Fourtanier & $\begin{array}{l}\text { Site 752, Paleocene-Eocene } \\
\text { diatom stratigraphy }\end{array}$ \\
\hline Nomura & $\begin{array}{l}\text { Maestrichtian-Eocene benthic } \\
\text { foraminifers }\end{array}$ \\
\hline
\end{tabular}

\section{Neogene}

\section{Biomagnetostratigraphy}

About $94 \mathrm{~m}$ of Neogene sediments were recovered from Hole 752A. The calcareous nannofossil and planktonic foraminifer stratigraphies are given by Resiwati (pers. comm.) and Jenkins and Gamson (pers. comm.), respectively. Because of the poor quality of whole core Natural Remanent Magnetization (NRM) data, low sedimentation rates $(<0.5 \mathrm{~cm} / \mathrm{k} . \mathrm{y}$.$) , and an inadequate$ density of discrete samples, no magnetostratigraphy was estab- lished for the Neogene of any Broken Ridge sites (Gee et al., this volume).

\section{Eocene-Oligocene}

Oligocene sediments were first encountered downhole in Core 121-752A-10H. Nannofossil oozes near the base of this core (Section 121-752A-10H-7) are placed in lower Oligocene nannofossil Subzone CP16a (Fig. 5). Sample 121-752A-10H-CC is placed in foraminifer Zones P18-P16, which agrees somewhat with the nannofossil data. Polarity is indeterminate through this interval and down to Section 121-752A-13X-3. Oligocene nannofossil Zones CP17-19 are missing with the disconformity separating lower Miocene sediments of Subzone CN1a from the lower Oligocene sediments of CP16a. Likewise, Oligocene-Miocene foraminifer Zones P22/N4 disconformably overlie P18-16 with P19-21 missing.

The sediments immediately overlying the prominent angular unconformity in Samples 121-752A-10H-CC to -12H-CC (94.7112.9 mbsf), including the detrital sand and gravel layer, are placed in uppermost Eocene nannofossil Subzone CP15b. This assignment is based on the presence of Isthmolithus recurvus with Discoaster saipanensis. It is in slight discord with the foraminifer data as this interval is assigned to middle Eocene Zones P14-13, normally correlative with nannofossil Zone CP14. This assignment is based on the presence of Acarinina coalingensis, Catapsydrax howei, Globigerina linaperta, and common A. densa.

The discrepancy might be accounted for in a number of ways. For the nannofossil zonal assignment, the presence of $I$. recurvus

Table 3. Nannofossil datum levels by sample for Site 752 and age assignments as correlated with Berggren et al. (1985).

\begin{tabular}{|c|c|c|c|c|}
\hline $\begin{array}{l}\text { Age } \\
(\mathrm{Ma})\end{array}$ & $\begin{array}{l}\text { Nannofossil } \\
\text { Zones }\end{array}$ & Event & Sample interval & $\begin{array}{l}\text { Mid-point depth } \\
\text { (mbsf) }\end{array}$ \\
\hline 21.5 & top $\mathrm{CN} 1$ & FO $S$. belemnos & $\begin{array}{l}752 \mathrm{~A}-9 \mathrm{H}-2,47-48 \mathrm{~cm} \\
-9 \mathrm{H}-3,47-48 \mathrm{~cm}\end{array}$ & 78.12 \\
\hline 25.2 & base $\mathrm{CN} 1$ & LO $S$. ciperoensis & $\begin{array}{l}-10 \mathrm{H}-7,47-48 \mathrm{~cm} \\
-10 \mathrm{H}-6,47-48 \mathrm{~cm}\end{array}$ & 93.72 \\
\hline \multicolumn{2}{|c|}{ Unconformity } & (CP19-CP16b) & $\begin{array}{l}-10 \mathrm{H}-7,47-48 \mathrm{~cm} \\
-10 \mathrm{H}, \mathrm{CC}\end{array}$ & 94.58 \\
\hline 36.7 & $\mathrm{CP} 16 \mathrm{a} / \mathrm{CP} 15 \mathrm{~b}$ & LO D. saipanensis & $\begin{array}{l}-11 \mathrm{H}-1,47-48 \mathrm{~cm} \\
-10 \mathrm{H}, \mathrm{CC}\end{array}$ & 94.93 \\
\hline \multicolumn{2}{|c|}{ Unconformity } & (CP15a-CP11) & $\begin{array}{l}-12 X, C C \\
-13 X-1,0 \mathrm{~cm}\end{array}$ & 112.90 \\
\hline 55.3 & $\mathrm{CP} 10 / \mathrm{CP} 9 \mathrm{~b}$ & FO D. lodoensis & $\begin{array}{l}-13 X-2,45-46 \mathrm{~cm} \\
-13 X-3,47-48 \mathrm{~cm}\end{array}$ & 115.05 \\
\hline 56.3 & $\mathrm{CP} 9 \mathrm{~b} / \mathrm{CP} 9 \mathrm{a}$ & LO $T$. contortus & $\begin{array}{l}-16 \times-3,47-48 \mathrm{~cm} \\
-16 X-1,47-48 \mathrm{~cm}\end{array}$ & 143.97 \\
\hline 57.6 & $\mathrm{CP} 9 \mathrm{a} / \mathrm{CP} 8$ & LO Fasciculithus spp. & $\begin{array}{l}-19 X-3,47-48 \mathrm{~cm} \\
-19 X-1,47-48 \mathrm{~cm}\end{array}$ & 173.06 \\
\hline 59.1 & $\mathrm{CP} 8 / \mathrm{CP} 7$ & FO D. multiradiatus & $\begin{array}{l}-22 X-2,47-48 \mathrm{~cm} \\
-22 X-3,47-48 \mathrm{~cm}\end{array}$ & 202.82 \\
\hline 59.8 & $\mathrm{CP} 7 / \mathrm{CP} 6$ & FO D. nobilis & $\begin{array}{l}-22 \mathrm{X}, \mathrm{CC} \\
-23 \mathrm{X}-1,47-48 \mathrm{~cm}\end{array}$ & 210.08 \\
\hline 60.4 & $\mathrm{CP} 6 / \mathrm{CP} 5$ & FO D. mohleri & $\begin{array}{l}-24 X-2,47-48 \mathrm{~cm} \\
-24 X, C C\end{array}$ & 225.77 \\
\hline 61.6 & $\mathrm{CP} 5 / \mathrm{CP} 4$ & $\mathrm{CO}$ H. Kleinpellii & $\begin{array}{l}-27 X-2,148-150 \mathrm{~cm} \\
-27 X-3,47-48 \mathrm{~cm}\end{array}$ & 251.60 \\
\hline 62.0 & $\mathrm{CP} 4 / \mathrm{CP} 3$ & FO $F$ tympaniformis & $\begin{array}{l}-32 X-3,47-48 \mathrm{~cm} \\
-32 X-5,47-48 \mathrm{~cm}\end{array}$ & 293.67 \\
\hline 63.7 & $\mathrm{CP} 3 / \mathrm{CP} 2$ & FO $P$. martinii & $\begin{array}{l}752 \mathrm{~B}-8 \mathrm{R}-5,22-23 \mathrm{~cm} \\
-8 \mathrm{R}-5,95-96 \mathrm{~cm}\end{array}$ & 330.99 \\
\hline 64.8 & $\mathrm{CP} 2 / \mathrm{CP} 1 \mathrm{~b}$ & FO C. danicus & $\begin{array}{l}-9 R, C C \\
-10 R-1,17-18 \mathrm{~cm}\end{array}$ & 345.18 \\
\hline 65.9 & $\mathrm{CP} 1 \mathrm{~b} / \mathrm{CP} 1 \mathrm{a}$ & FO C. tenuis & $\begin{array}{l}-10 \mathrm{R}-6,135-136 \mathrm{~cm} \\
-10 \mathrm{R}-7,17-18 \mathrm{~cm}\end{array}$ & 354.11 \\
\hline 66.4 & $\mathrm{CP} 1 \mathrm{a} / \mathrm{CC} 26$ & $\mathrm{~K} / \mathrm{T}$ boundary & $\begin{array}{l}-11 \mathrm{R}-3,92-93 \mathrm{~cm} \\
-11 \mathrm{R}-3,101-102 \mathrm{~cm}\end{array}$ & 358.76 \\
\hline a 70.4 & $\mathrm{CC} 25 / \mathrm{CC} 24$ & LO $R$. levis & $\begin{array}{l}-17 \mathrm{R}-3,105-106 \mathrm{~cm} \\
-17 \mathrm{R}-1,2-3 \mathrm{~cm}\end{array}$ & 414.63 \\
\hline
\end{tabular}

Note: $\mathrm{FO}=$ first occurrence; $\mathrm{LO}=$ last occurrence.

a The age of the LO of Reinhardtites levis is not well constrained and is roughly estimated here at $70.4 \mathrm{Ma}$. 
Table 4. Foraminifer datum levels by sample for Site 752 and age assignments as correlated with Berggren et al. (1985).

\begin{tabular}{|c|c|c|c|c|}
\hline $\begin{array}{l}\text { Age } \\
(\mathrm{Ma})\end{array}$ & $\begin{array}{l}\text { Foraminifer } \\
\text { Zones }\end{array}$ & Event & Sample interval & $\begin{array}{l}\text { Mid-point depth } \\
\text { (mbsf) }\end{array}$ \\
\hline \multicolumn{3}{|c|}{ Unconformity $\quad$ (P19-P21) } & $\begin{array}{l}752 \mathrm{~A}-10 \mathrm{H}-2,110-115 \mathrm{~cm} \\
-10 \mathrm{H}, \mathrm{CC}\end{array}$ & 89.66 \\
\hline \multicolumn{2}{|c|}{ Unconformity } & P15) & $\begin{array}{l}-10, C C \\
-11 \mathrm{H}-3,110-115 \mathrm{~cm}\end{array}$ & 97.40 \\
\hline 43.0 & P13-14/P10-12 & LO G. frontosa & $\begin{array}{l}-13 X-3,5-8 \mathrm{~cm} \\
-12 X, C C\end{array}$ & 114.43 \\
\hline 52.0 & P10-12/P6-9 & FO G. frontosa & $\begin{array}{l}-14 X, C C \\
-15 X, C C\end{array}$ & 137.15 \\
\hline 58.2 & P6-9/P5 & LO G. velascoensis & $\begin{array}{l}-18 \mathrm{X}, \mathrm{CC} \\
-17 \mathrm{X}, \mathrm{CC}\end{array}$ & 166.25 \\
\hline 58.8 & $\mathrm{P} 5 / \mathrm{P} 3 \mathrm{~b}-4$ & LO $P$. pseudomenardii & $\begin{array}{l}-22 \mathrm{X}, \mathrm{CC} \\
-22 \mathrm{X}-3,110-115 \mathrm{~cm}\end{array}$ & 206.50 \\
\hline 62.0 & $\mathrm{P} 3 \mathrm{~b}-4 / \mathrm{P} 3 \mathrm{a}$ & $\begin{array}{c}\text { FO A. coalingensis } \\
\text { A. mckannai }\end{array}$ & $\begin{array}{l}-28 \mathrm{X}, \mathrm{CC} \\
-29 \mathrm{X}, \mathrm{CC}\end{array}$ & 272.55 \\
\hline 62.3 & $\mathrm{P} 3 \mathrm{a} / \mathrm{P} 2$ & FO $M$, angulata & $\begin{array}{l}-30 \mathrm{X}, \mathrm{CC} \\
-31 \mathrm{X}, \mathrm{CC}\end{array}$ & 284.05 \\
\hline 63.0 & $\mathrm{P} 2 / \mathrm{P} 1 \mathrm{~b}$ & FO $M$. uncinata & $\begin{array}{l}-31 \mathrm{X}, \mathrm{CC} \\
752 \mathrm{~B}-5 \mathrm{R}-1,118-121 \mathrm{~cm}\end{array}$ & 293.45 \\
\hline 66.1 & P1b/P1a & $\begin{array}{c}\text { LO G. fringa } \\
G \text {. edita }\end{array}$ & $\begin{array}{l}-9 \mathrm{R}-1,56-59 \mathrm{~cm} \\
-8 \mathrm{R}, \mathrm{CC}\end{array}$ & 335.66 \\
\hline 66.4 & $\mathrm{P} 1 \mathrm{a} /$ A. mayaroensis & LO Cretaceous spp. & $\begin{array}{l}-11 \mathrm{R}-3,96-97 \mathrm{~cm} \\
-11 \mathrm{R}-3,88-89 \mathrm{~cm}\end{array}$ & 358.72 \\
\hline 69.9 & $\begin{array}{c}\text { A. mayaroensis/ } \\
\text { G. gansseri }\end{array}$ & FO A. mayaroensis & $\begin{array}{l}-17 \mathrm{R}-1,106-109 \mathrm{~cm} \\
-17 \mathrm{R}, \mathrm{CC}\end{array}$ & 417.99 \\
\hline
\end{tabular}

Note: $\mathrm{FO}=$ first occurrence; LO $=$ last occurrence.

Table 5. Diatom datum levels by sample for Site $\mathbf{7 5 2}$ and age assignments as correlated with Berggren et al. (1985).

\begin{tabular}{|c|c|c|c|c|}
\hline Age (Ma) & $\begin{array}{c}\text { Diatom } \\
\text { Zones/Subzones } \\
\text { Fourtanier (this volume) }\end{array}$ & Event & Sample interval & $\begin{array}{l}\text { Mid-point depth } \\
\text { (mbsf) }\end{array}$ \\
\hline & Barren & & $\begin{array}{c}\text { Cores } 752 \mathrm{~A}-9 \mathrm{H} \\
-12 \mathrm{X}\end{array}$ & \\
\hline $56.30-56.65$ & base of Pyxilla gracilis & FO Pyxilla gracilis & $\begin{array}{l}-17 \mathrm{X}, \mathrm{CC} \\
18 \mathrm{X}-1,38-40 \mathrm{~cm}\end{array}$ & 159.37 \\
\hline $56.65-56.80$ & & LO Hemiaulus incurvus & $\begin{array}{l}-18 X-1,38-40 \mathrm{~cm} \\
-18 X-2,53-55 \mathrm{~cm}\end{array}$ & 162.61 \\
\hline $56.85-57.40$ & & $\begin{array}{l}\text { FO Hemiaulus peripterus } \\
\text { var. longispinus }\end{array}$ & $\begin{array}{l}-18 X, C C \\
-19 X-1,55-57 \mathrm{~cm}\end{array}$ & 167.90 \\
\hline $57.65-57.95$ & base of Hemiaulus incurvus C & LO Trinacria aries & $\begin{array}{l}-19 X-3,55-57 \mathrm{~cm} \\
-20 X-1,55-57 \mathrm{~cm}\end{array}$ & 177.95 \\
\hline $58.35-58.65$ & & FO Triceratium orbiculatum & $\begin{array}{l}-21 \mathrm{X}, \mathrm{CC} \\
-22 \mathrm{X}-1,55-57 \mathrm{~cm}\end{array}$ & 197.10 \\
\hline $60.75-60.80$ & base of Hemiaulus incurvus B & $\begin{array}{l}\text { LO Triceratium gombosii } \\
\text { var. A }\end{array}$ & $\begin{array}{l}-25 \mathrm{X}-3,51-53 \mathrm{~cm} \\
-25 \mathrm{X}, \mathrm{CC}\end{array}$ & 232.97 \\
\hline $60.95-61.05$ & & FO T. gombosii & $\begin{array}{l}-26 \mathrm{X}-1,55-57 \mathrm{~cm} \\
-26 \mathrm{X}-3,55-57 \mathrm{~cm}\end{array}$ & 240.85 \\
\hline $61.55-61.60$ & & $\begin{array}{l}\text { LO } H \text {. peripterus var. } \\
\text { peripterus }\end{array}$ & $\begin{array}{l}-28 \mathrm{X}-1,55-57 \mathrm{~cm} \\
-28 \mathrm{X}-2,100-102 \mathrm{~cm}\end{array}$ & 259.62 \\
\hline $61.60-61.65$ & $\begin{array}{c}\text { base of Hemiaulus incurvus A } \\
\text { Barren }\end{array}$ & FO Hemiaulus incurvus & $\begin{array}{c}-28 \mathrm{X}-2,100-102 \mathrm{~cm} \\
-28 \mathrm{X}-3,57-58 \mathrm{~cm} \\
\text { Cores } 752 \mathrm{~A}-32 \mathrm{X}- \\
752 \mathrm{~B}-19 \mathrm{R}\end{array}$ & 261.13 \\
\hline
\end{tabular}

Note: $\mathrm{FO}=$ first occurrence; $\mathrm{LO}=$ last occurrence.

in Sample 121-752A-12X-CC indicates an assignment no older than uppermost Eocene (CP15b). However, recovery was about $2 \%$ in this core, which was drilled through unconsolidated sands and gravels. Caving could have allowed upper Eocene sediments containing $I$. recurvus to fall down the hole. Interestingly, Resiwati (pers. comm.) originally had placed Sections 121-752A$11 \mathrm{H}-3$ to $-12 \mathrm{X}-\mathrm{CC}$ in Zone CP14, perhaps a testament to the amount of reworking. Zone CP14 correlates better with the foraminifer zonal assignment, but additional search and discovery of I. recurvus in Core 121-752A-12X changed that assignment.
Conversely, the foraminifer assignment may be too old. The sediments of this interval lie above an erosional disconformity, hence reworking might be expected which could easily lead to an older age assignment. Reworked nannofossils are present as mentioned before and, according to van Eijden and Smit (this volume), reworking of planktonic foraminifers is possible, although not easily detected because of low diversity and the presence of long-ranging forms. Nomura (this volume) notes that the rare presence of the benthic form, Alabamina dissonata in Sections $121-752 \mathrm{~A}-11 \mathrm{H}-3$ and $-11 \mathrm{H}-4$ may be the result of reworking. This 
Table 6. Magnetic chron boundaries by sample for Site 752 and age assignments as correlated with Berggren et al. (1985).

\begin{tabular}{|c|c|c|c|}
\hline $\begin{array}{l}\text { Age } \\
(\mathrm{Ma})\end{array}$ & Reversal boundary & Sample interval & $\begin{array}{l}\text { Mid-point depth } \\
\text { (mbsf) }\end{array}$ \\
\hline & base of indeterminate zone & $752 \mathrm{~A}-13 \mathrm{X}-3,85 \mathrm{~cm}$ & 116.50 \\
\hline 55.14 & $\mathrm{C} 23 \mathrm{R} / \mathrm{C} 24 \mathrm{~N}-1$ & - & $118.40-122.60$ \\
\hline 55.37 & $\mathrm{C} 24 \mathrm{~N}-1 / \mathrm{C} 24 \mathrm{R}-1$ & $\begin{array}{l}-14 X-3,122 \mathrm{~cm} \\
-14 X-4,9 \mathrm{~cm}\end{array}$ & 127.50 \\
\hline 55.66 & $\mathrm{C} 24 \mathrm{R}-1 / \mathrm{C} 24 \mathrm{~N}-2$ & $\begin{array}{l}-15 X-2,75 \mathrm{~cm} \\
-15 X-3,60 \mathrm{~cm}\end{array}$ & 135.00 \\
\hline 56.14 & $\mathrm{C} 24 \mathrm{~N}-2 / \mathrm{C} 24 \mathrm{R}-2$ & $\begin{array}{l}-17 X-2,121 \mathrm{~cm} \\
-17 X-3,60 \mathrm{~cm}\end{array}$ & 154.90 \\
\hline 58.64 & $\mathrm{C} 24 \mathrm{R}-2 / \mathrm{C} 25 \mathrm{~N}$ & $\begin{array}{l}-22 \mathrm{X}-1,41 \mathrm{~cm} \\
-22 \mathrm{X}-2,4 \mathrm{~cm}\end{array}$ & 201.10 \\
\hline 59.24 & $\mathrm{C} 25 \mathrm{~N} / \mathrm{C} 25 \mathrm{R}$ & - & $211.50-219.50$ \\
\hline 60.21 & $\mathrm{C} 25 \mathrm{R} / \mathrm{C} 26 \mathrm{~N}$ & - & $221.70-229.10$ \\
\hline 60.75 & $\mathrm{C} 26 \mathrm{~N} / \mathrm{C} 26 \mathrm{R}$ & $\begin{array}{l}-25 X-2,111 \mathrm{~cm} \\
-25 X-3,73 \mathrm{~cm}\end{array}$ & 232.10 \\
\hline 63.03 & $\mathrm{C} 26 \mathrm{R} / \mathrm{C} 27 \mathrm{~N}$ & - & $303.60-306.70$ \\
\hline 63.54 & $\mathrm{C} 27 \mathrm{~N} / \mathrm{C} 27 \mathrm{R}$ & $\begin{array}{l}752 \mathrm{~B}-6 \mathrm{R}-3,102 \mathrm{~cm} \\
-6 \mathrm{R}-4,147 \mathrm{~cm}\end{array}$ & 312.20 \\
\hline 64.29 & $\mathrm{C} 27 \mathrm{R} / \mathrm{C} 28 \mathrm{~N}$ & - & $336.80-345.10$ \\
\hline 65.12 & $\mathrm{C} 28 \mathrm{~N} / \mathrm{C} 28 \mathrm{R}$ & $\begin{array}{l}-10 \mathrm{R}-1,16 \mathrm{~cm} \\
-10 \mathrm{R}-1,35 \mathrm{~cm}\end{array}$ & $\mathrm{a}_{345.30}$ \\
\hline \multirow[t]{3}{*}{65.50} & $\mathrm{C} 28 \mathrm{R} / \mathrm{C} 29 \mathrm{~N}$ & $\begin{array}{l}-10 \mathrm{R}-1,103 \mathrm{~cm} \\
-10 \mathrm{R}-2,38 \mathrm{~cm}\end{array}$ & $\mathrm{a}_{346.80}$ \\
\hline & top of indeterminate zone & $\begin{array}{l}-10 \mathrm{R}-6,32 \mathrm{~cm} \\
-10 \mathrm{R}-6,61 \mathrm{~cm}\end{array}$ & $a_{353.10}$ \\
\hline & base of indeterminate zone & $-11 \mathrm{R}-2, \overline{92} \mathrm{~cm}$ & $a_{357.20}$ \\
\hline \multirow[t]{3}{*}{66.74} & $\mathrm{C} 29 \mathrm{R} / \mathrm{C} 30 \mathrm{~N}$ & $-12 \mathrm{R}-1, \overline{61} \mathrm{~cm}$ & $b_{364.70}$ \\
\hline & top of reversed zone & $\begin{array}{l}-14 \mathrm{R}-1,26 \mathrm{~cm} \\
-14 \mathrm{R}-1,129 \mathrm{~cm}\end{array}$ & $a_{384.80}$ \\
\hline & base of reversed zone & $\begin{array}{l}-14 \mathrm{R}-2,124 \mathrm{~cm} \\
-14 \mathrm{R}-3,14 \mathrm{~cm}\end{array}$ & ${ }^{a} 386.40$ \\
\hline 68.42 & $\mathrm{C} 30 \mathrm{~N} / \mathrm{C} 30 \mathrm{R}$ & $\begin{array}{l}-14 \mathrm{R}-3,66 \mathrm{~cm} \\
-14 \mathrm{R}-4,28 \mathrm{~cm}\end{array}$ & ${ }^{a} 387.50$ \\
\hline 68.52 & $\mathrm{C} 30 \mathrm{R} / \mathrm{C} 31 \mathrm{~N}$ & - & ${ }^{a} 392.90-393.30$ \\
\hline 69.40 & $\mathrm{C} 31 \mathrm{~N} / \mathrm{C} 31 \mathrm{R}$ & $\begin{array}{l}-15 \mathrm{R}-2,115 \mathrm{~cm} \\
-15 \mathrm{R}-3,4 \mathrm{~cm}\end{array}$ & 396.20 \\
\hline
\end{tabular}

a Identification or precise depth suspect. See discussion in Gee et al. (this volume).

${ }^{b}$ Based on whole core data. is a lower bathyal to abyssal form which is much more common in the lower Eocene at this site.

The (pre-rift) sediments immediately below the angular unconformity down to Sample 121-752A-13X-2, 47-48 cm (114.3 mbsf), at Site 752 are placed in lower Eocene Zone CP10 based on the presence of both $D$. lodoensis and Tribrachiatus orthostylus. The section below this down to Sample 121-752A-19X-1, $47-48 \mathrm{~cm}$, is assigned to lower Eocene Zone CP9. Nannofossil Zones CP11-CP14 are not present. Foraminifers indicate that the upper part of this interval is slightly younger (middle Eocene). Cores $121-752 \mathrm{~A}-13 \mathrm{X}$ to $-15 \mathrm{X}$ are placed in combined foraminifer Zones P12-10 based on the presence of Globigerina frontos $a$ and Morozovella aragonensis. In closer agreement with the nannofossil data, Gee et al. (this volume) assign Core 121-752A-13X to the lower Eocene Chron 23R and place the C23R/C24N boundary between Cores 121-752A-13X and -14X. The interval of nannofossil Zone CP9 encompasses the C24N/C24R boundary, which is in good agreement with the time scale of Berggren et al. (1985). In addition, diatoms, present in abundance for the first time downhole, suggest a lower Eocene Pyxilla gracilis Zone assignment for Cores 121-752A-13X to -17X (Fourtanier, this volume).

The Paleocene/Eocene boundary, as approximated by nannofossils, is placed between Samples 121-752A-19X-1, 47-48 cm, and $-19 \mathrm{X}-3,47-48 \mathrm{~cm}(\sim 173.06 \mathrm{mbsf})$. The last occurrence (LO) of Fasciculithus spp. is used to mark this transition and the CP8/CP9 zonal boundary. The boundary, as indicated by the LO of the foraminifer Globigerina velascoensis (roughly the P6/P5 boundary), is placed no lower than the base of Core 121-752A$18 \mathrm{X}$, in fairly good agreement with the nannofossils. The LO of the diatom, Trinacria aries, which marks the Hemiaulus incurvus B/C Subzone boundary is placed between Samples 121-752A$19 \mathrm{X}-3,55-57 \mathrm{~cm}$, and $-20 \mathrm{X}-1,55-57 \mathrm{~cm}$ ( 177.95 mbsf), and approximates the Paleocene/Eocene boundary as defined by calcareous nannofossils. The benthic foraminifer extinction is noted at this site between Samples 121-752A-19X-3, 75-79 cm, and $-20 \mathrm{X}-1,70-75 \mathrm{~cm}$, which is slightly lower than the Paleocene/Eocene boundary (Nomura, this volume). In agreement with the time scale of Berggren et al. (1985), the Paleocene/Eocene boundary does fall within C24R at this site.

Table 7. Nannofossil and foraminifer datum levels by sample for Sites 753-755 and age assignments as correlated with Berggren et al. (1985) (Tertiary) and Kent and Gradstein (1985) (Cretaceous).

\begin{tabular}{|c|c|c|c|c|}
\hline $\begin{array}{l}\text { Age } \\
\text { (Ma) }\end{array}$ & $\begin{array}{l}\text { Nannofossil// } \\
\text { Foraminifer } \\
\text { Zones }\end{array}$ & Event & Sample interval & $\begin{array}{l}\text { Mid-point depth } \\
\text { (mbsf) }\end{array}$ \\
\hline \multicolumn{5}{|l|}{ Hole 753A } \\
\hline 47.0 & $\mathrm{CP} 13 \mathrm{c} / \mathrm{CP} 13 \mathrm{~b}$ & LO C. gigas & $\begin{array}{l}753 \mathrm{~A}-7 \mathrm{H}-3,47-48 \mathrm{~cm} \\
-7 \mathrm{H}-1,47-48 \mathrm{~cm}\end{array}$ & 54.17 \\
\hline \multicolumn{5}{|l|}{ Hole 754B } \\
\hline 69.9 & base of $A$. mayaroensis & FO $A$. mayaroensis & $\begin{array}{l}754 \mathrm{~B}-5 \mathrm{R}, \mathrm{CC} \\
-6 \mathrm{R}-1,110-113 \mathrm{~cm}\end{array}$ & 162.50 \\
\hline${ }^{\mathrm{a}} 72.5 ?$ & $\mathrm{CC} 24 / \mathrm{CC} 23 \mathrm{~b}$ & LO T. phacelosus & $\begin{array}{l}\text { 754B-11R, CC } \\
-11 \mathrm{R}-1,47-48 \mathrm{~cm}\end{array}$ & 214.64 \\
\hline \multicolumn{5}{|l|}{ Hole 755A } \\
\hline a $86.0 ?$ & $\mathrm{CC} 16 / \mathrm{CC} 15$ & & $\begin{array}{l}755 \mathrm{~A}-7 \mathrm{R}, \mathrm{CC} \\
-8 \mathrm{R}-1,24-25 \mathrm{~cm}\end{array}$ & 91.62 \\
\hline a $86.0 ?$ & $\mathrm{CC} 15 / \mathrm{CC} 14$ & & $\begin{array}{l}-10 \mathrm{R}-1,38-39 \mathrm{~cm} \\
-10 \mathrm{R}-2,43-44 \mathrm{~cm}\end{array}$ & 112.10 \\
\hline a $88.0 ?$ & base $\mathrm{CC} 14$ & & $\begin{array}{l}-12 R, C C \\
-13-1,52-53 \mathrm{~cm}\end{array}$ & 141.06 \\
\hline
\end{tabular}

a The ages of the Turonian-Maestrichtian nannofossil datums are not well constrained and are only roughly estimated from correlations with the time scale of Kent and Gradstein (1985). 
Table 8. Magnetic chron boundaries by sample for Sites 753-755 and age assignments as correlated with Berggren et al. (1985).

\begin{tabular}{|c|c|c|c|}
\hline $\begin{array}{l}\text { Age } \\
\text { (Ma) }\end{array}$ & Reversal boundary & Sample interval & $\begin{array}{l}\text { Mid-point depth } \\
\text { (mbsf) }\end{array}$ \\
\hline \multicolumn{4}{|l|}{ Hole $753 \mathrm{~A}$} \\
\hline $\begin{array}{l}46.17 \\
42.73\end{array}$ & $\begin{array}{l}{ }^{a} \mathrm{C} 20 \mathrm{~N} / \mathrm{C} 20 \mathrm{R} \text { or } \\
{ }^{\mathrm{c}} \mathrm{C} 18 \mathrm{~N} / \mathrm{C} 18 \mathrm{R}\end{array}$ & $\begin{array}{l}753 \mathrm{~A}-6 \mathrm{H}-2,63 \mathrm{~cm} \\
-6 \mathrm{H}-3,63 \mathrm{~cm}\end{array}$ & $b_{46.60}$ \\
\hline \multicolumn{4}{|l|}{ Hole 754B } \\
\hline & base of normal zone & $\begin{array}{l}\text { 754B-5R-2, } 115 \mathrm{~cm} \\
-5 \mathrm{R}-3,109 \mathrm{~cm}\end{array}$ & $\mathrm{~b}_{154.90}$ \\
\hline 71.37 & C 31 R?/C32N-1 & $\begin{array}{l}-7 \mathrm{R}-4,29 \mathrm{~cm} \\
-7 \mathrm{R}-5,35 \mathrm{~cm}\end{array}$ & 176.60 \\
\hline 71.65 & $\mathrm{C} 32 \mathrm{~N}-1 / \mathrm{C} 32 \mathrm{R}-1$ & $\begin{array}{l}-9 \mathrm{R}-1,17 \mathrm{~cm} \\
-9 \mathrm{R}-2,110 \mathrm{~cm}\end{array}$ & 191.70 \\
\hline 71.91 & $\mathrm{C} 32 \mathrm{R}-1 / \mathrm{C} 32 \mathrm{~N}-2$ & $\begin{array}{l}-11 \mathrm{R}-1,123 \mathrm{~cm} \\
-11 \mathrm{R}-2,24 \mathrm{~cm}\end{array}$ & 211.10 \\
\hline & $\begin{array}{l}\text { top of reversed zone } \\
\text { base of reversed zone }\end{array}$ & - & $\begin{array}{l}b_{212.60-219.20} \\
b_{220.70-229.90}\end{array}$ \\
\hline 73.55 & base of $\mathrm{C} 32 \mathrm{~N}-2$ & - & $299.30-306.30$ \\
\hline \multicolumn{4}{|l|}{ Hole 755A } \\
\hline & $\mathrm{C} 34 \mathrm{~N}$ & Cores $755 \mathrm{~A}-5 \mathrm{R}$ to $755 \mathrm{R}-19 \mathrm{R}$ & \\
\hline
\end{tabular}

\footnotetext{
a Original interpretation of Gee et al. (this volume).

${ }^{b}$ Identification or precise depth suspect. See discussion in Gee et al. (this volume).

c Alternate interpretation discussed in this paper.
}

\section{Paleocene}

The interval from Core 121-752A-18X to the Cretaceous/Tertiary boundary at Sample 121-752B-11R-3, 94-95 cm ( 173.0$358.7 \mathrm{mbsf}$ ), comprises a complete and fairly expanded Paleocene section, which encompasses nannofossil Zones CP8-CP1, foraminifer Zones P5-P1, and Chrons C24R-C29R. Nannofossils, for the most part, are moderately to well preserved in this interval. Foraminifers, on the other hand, exhibit poor preservation in the Paleocene section, notably in the Danian Zone P1a. The Paleocene diatom zones Hemiaulus incurvus $\mathrm{B}-\mathrm{A}$ and the $H$. peripterus are recognized; however, because of dissolution, diatoms are rare to absent below about Core 121-752A-31X in the lower Paleocene. Opal-CT present below this level and in the Maestrichtian sediments is indicative of high siliceous plankton productivity during this time.

The uppermost Paleocene nannofossil Zone CP8 (Discoaster multiradiatus) is assigned to Samples 121-752A-19X-3, 47-48 $\mathrm{cm}$, to $-22 \mathrm{X}-2,47-48 \mathrm{~cm}$ ( 173.06-202.82 mbsf). This corresponds to foraminifer Zone P5 (Morozovella velascoensis) and encompasses the upper part of the Hemiaulus incurvus B Subzone and the lower part of Subzone C. The base of C24R is placed at Sample 121-752A-22X-1, $41 \mathrm{~cm}$, and the nannofossil CP8/CP7 and the foraminifer P5/P4 boundaries fall just within $\mathrm{C} 25 \mathrm{~N}$ (in agreement with the time scale of Berggren et al., 1985).

Upper Paleocene nannofossil Zone CP7 is a short interval based on the FO (first occurrence) of Discoaster nobilis, occurring in Samples 121-752A-22X-3, 47-48 cm, to -22X-CC (209.8 mbsf). The base of the underlying Zone CP6 is marked by the FO of D. mohleri in Sample 121-752A-24X-2, 47-48 cm (220.97 mbsf), and the base of Zone CP5 is placed at the FO Heliolithus kleinpellii in Sample 121-752A-27X-2, 148-150 cm (248.87 mbsf). In agreement with Berggren et al. (1985), Zones CP7 and CP6 correlate well with the upper part of foraminifer Zone P4 as assigned here. According to Berggren et al. (1985), the CP6/CP5 boundary should fall within $\mathrm{C} 26 \mathrm{~N}$; however, here it falls above this and within a reversed interval assigned to C25R. This possibly results from diachroneity in the first occurrences of some nannofossil marker species, particularly $D$. mohleri, which may be expected for higher latitude paleolocalities. For example, a later first occurrence of this species was noted at Site $690\left(65^{\circ} \mathrm{S}\right)$ in the Weddell Sea (Pospichal and Wise, 1990).

Because of the rare occurrence of Planorotalites pseudomenardii and the lack of keeled Morozovella species, foraminifer Zones P $3 \mathrm{~b}$ and P4 could not be accurately distinguished. The upper part of $\mathrm{P} 4$ can be inferred, as mentioned above, by correlation with nannofossil Zones CP6-7. The base of P3b can be delimited by the FO of Acarinina coalingensis and A. mckannai in Sample 121-752A-28X-CC (267.7 mbsf). According to Berggren et al. (1985), the base of this zone should correspond roughly to base of nannofossil Zone CP4 and fall within C26R. Here, the base of CP4 (FO Fasciculithus spp.) is placed below the P3b/3a boundary at Sample 121-752A-32X-3, 47-48 cm (292.97 mbsf), but still within C26R.

Also correlative with $\mathrm{C} 26 \mathrm{R}$ is the diatom Hemiaulus incurvus Subzone A, which is assigned to the interval from Sample 121$752 \mathrm{~A}-25 \mathrm{X}-3,51-53 \mathrm{~cm}$, to the FO of $H$. incurvus in Sample 121-752A-28X-2, 100-102 cm. This zone encompasses the CP4/CP5 boundary and correlates with the lower part of P4-P3b. The section down to $121-752 \mathrm{~A}-31 \mathrm{X}-\mathrm{CC}$ is assigned to the Hemiaulus peripterus Zone, which falls entirely within CP4 and includes the lowest part of P4-P3b down to the base of P2.

Only a slight discrepancy is present between nannofossil and foraminifer stratigraphies in this part of the Paleocene as foraminifer Zones P3a-P2 are correlated with the lower part of CP4. On the Berggren et al. scale, Zones P3a-P2 correspond to the upper part of CP3 (C26R). The P3a/P2 boundary is placed at Sample 121-752A-30X-CC (279.4 mbsf) based on the FO of Morozovella angulata, and Zone P2 (FO Morozovella uncinata) is assigned to the section down to Sample 121-752A-31X-CC (288.7 mbsf), just above the nannofossil CP4/CP3 boundary (292.97 mbsf).

The $\mathrm{C} 26 \mathrm{R} / \mathrm{C} 27 \mathrm{~N}$ boundary is placed between Cores 121$752 B-5 R$ and $-6 R$ and falls within nannofossil Zone CP3 and foraminifer Zone P1b. This interpretation is in accord with Berggren et al. (1985) except for the correlation with P1b, which is interpreted by Berggren et al. to correspond to C28N and C29N. 


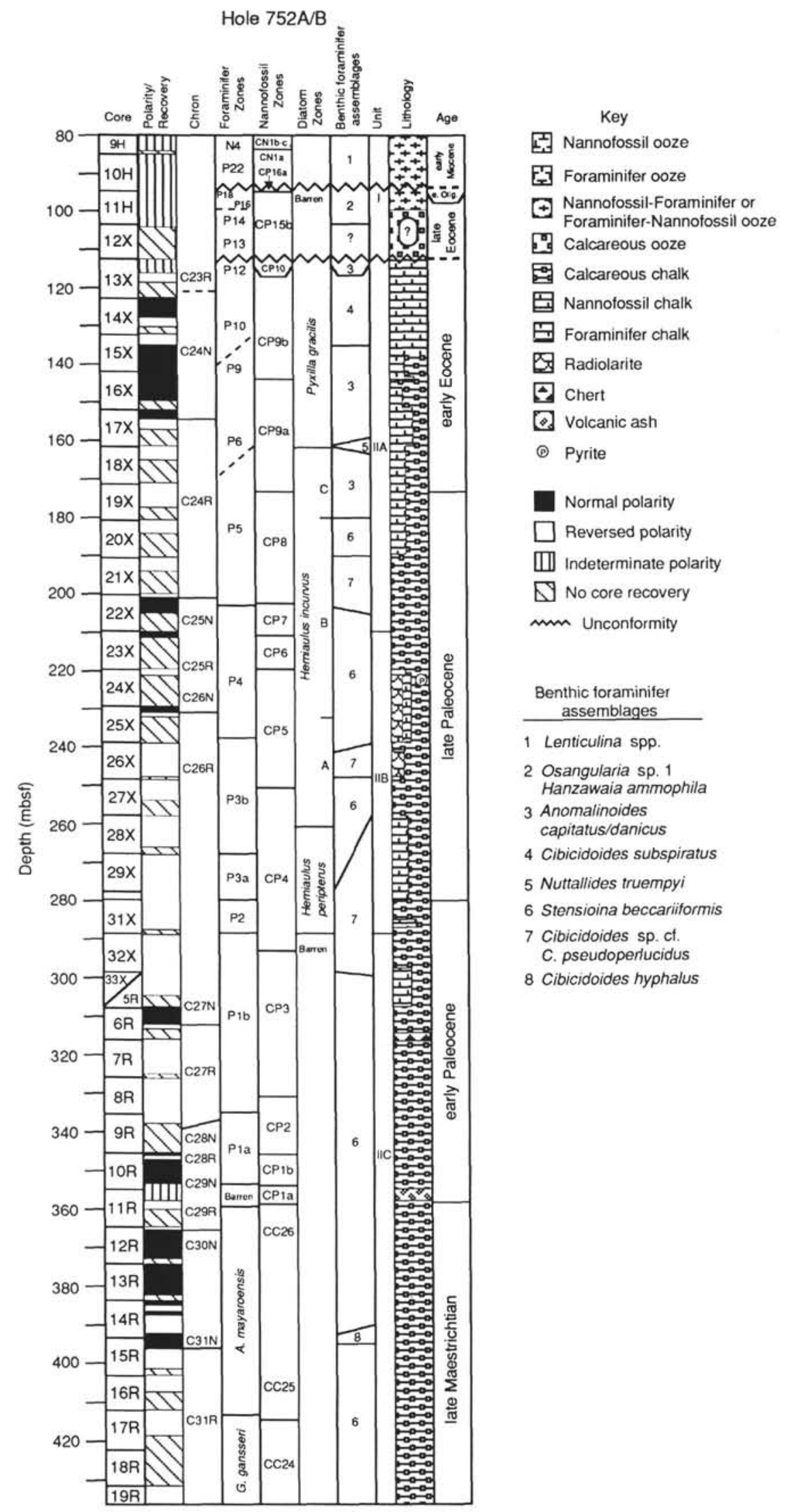

Figure 5. Lithologic and biomagnetostratigraphic summary of Holes 752A-752B. Core recovery is represented in the same column as the polarity. 
However, Zone P1c is not recognized here, which may in part account for this disagreement.

The nannofossil CP3/CP2 zonal boundary is normally determined by the FO of Ellipsolithus macellus, but because of the rare and inconsistent occurrence of this species, especially in higher latitudes, the FO of Prinsius martinii can be used as an alternative (Perch-Nielsen, 1985). This occurs in Sample 121-752B-8R-5, $22-23 \mathrm{~cm}$ (330.63 mbsf), within C27R, as Berggren et al. suggest. Just below this level and still within C27R, the foraminifer $\mathrm{P} 1 \mathrm{~b} / \mathrm{P} 1 \mathrm{a}$ boundary is delineated by the LO of Globigerina fringa and $G$. edita in Sample 121-752B-9R-1, 56-59 cm (335.97 mbsf).

The FO of Chiasmolithus danicus in Sample 121-752B-9R-CC ( $345.1 \mathrm{mbsf}$ ) is indicative of the base of nannofossil Zone $\mathrm{CP} 2$, and the FO of Cruciplacolithus tenuis in Sample 121-752B-10R-6, $135-136 \mathrm{~cm}$ (353.95 mbsf), denotes the CP1b/CP1a boundary. Zones CP2 and CP1b of Cores 121-752B-9R and -10R correspond to the foraminifer Zone $\mathrm{P} 1 \mathrm{a}$, which is characterized by the presence of $G$. fring $a$ and $G$. edita. Foraminifer preservation is poor in these cores and samples are barren from Section 121-752B$10 \mathrm{R}-7$ to Sample $121-752 \mathrm{~B}-11 \mathrm{R}-3,88-89 \mathrm{~cm}$, at the Cretaceous/Tertiary boundary. Nannofossil Zones CP2-CP1b correspond to the lower part of Zones P1c and P1b according to Berggren et al. (1985), and the discrepancy here may be the result of poor foraminifer preservation in addition to the possible diachroneity of microfossil events associated with a higher latitude location.

Rapid polarity changes occur in Core 121-752B-10R of the lowermost Paleocene, nevertheless, the magnetostratigraphy and nannofossil biostratigraphy remain in fairly good agreement. The $\mathrm{C} 27 \mathrm{R} / \mathrm{C} 28 \mathrm{~N}$ boundary is interpreted to lie between Core 121$752 \mathrm{~B}-9 \mathrm{R}$ and the top of Core 121-752B-10R, where the CP2/ $\mathrm{CP} 1 \mathrm{~b}$ boundary is also placed. Following Berggren et al., this nannofossil boundary should lie within $\mathrm{C} 28 \mathrm{~N}$ where it probably does occur; however, poor recovery in Core 121-752B-9R (17\%) precludes a more precise determination. The top of Core 121$752 \mathrm{~B}-10 \mathrm{R}$ to Sample 121-752B-10R-1, $16 \mathrm{~cm}$ (345.26 mbsf), is assigned to $\mathrm{C} 28 \mathrm{~N}$ with the underlying short section down to Sample 121-752B-10R-1, $103 \mathrm{~cm}$ (346.03 mbsf), belonging to C28R. As on the Berggren et al. (1985) scale, the C28N/C28R and C28R/C29N boundaries fall within nannofossil Subzone CP1b. The C29N/C29R boundary unfortunately lies within a zone of indeterminate polarity from Samples $121-752 \mathrm{~B}-10 \mathrm{R}-6,32 \mathrm{~cm}$, to $-11 \mathrm{R}-2,92 \mathrm{~cm}$ (352.92-353.21 mbsf), an interval which also includes the CP1b/CP1a boundary. Hence, there is no way to discern if this nannofossil boundary lies within C29N as Berggren et al. (1985) suggest.

\section{Cretaceous/Tertiary Boundary}

The Cretaceous/Tertiary boundary lies at the base of an $\sim 6 \mathrm{~m}$ thick section of multiple volcanic ash layers. Chert and porcellanite are present at and immediately above the boundary, which is above ash-rich upper Maestrichtian chalks. The indurated sediments of the boundary interval consist of numerous "drilling biscuits" (broken and rotated pieces of the cored sediment) produced by the rotary coring process (Fig. 6). Some sediment could have been lost between these biscuits, thus caution must be taken when interpreting results from this section. However, the boundary interval is biostratigraphically complete in addition to being one of the most expanded recovered by ODP/DSDP. The $\sim 5 \mathrm{~m}$ thick nannofossil Zone CP1a is comparable to expanded sections such as that at El Kef, Tunisia, which is considered a standard for comparison.

According to the nannofossils, the boundary lies between Samples 121-752B-11R-3, 92-93 cm, and $-11 \mathrm{R}-3,101-102 \mathrm{~cm}$ ( $358.76 \mathrm{mbsf})$, based on the increase in the number of species known as "survivors," such as Zygodiscus sigmoides, Markalius

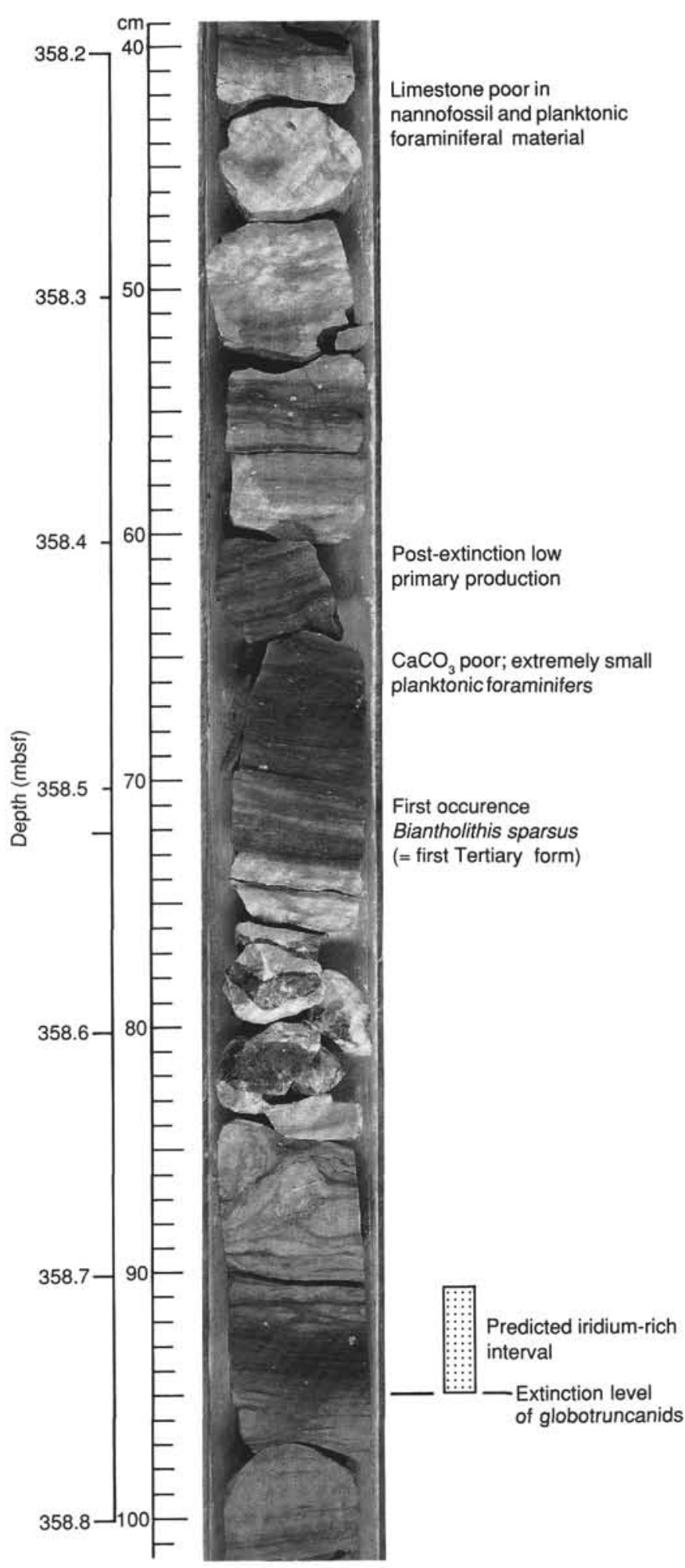

Figure 6. The numerous drilling biscuits of the Cretaceous/Tertiary boundary interval of Section 121-752B-11R-3, 40-100 cm. The boundary is located at $\sim 94 \mathrm{~cm}$ ( $358.75 \mathrm{mbsf}$ ) at the level of the iridium anomaly (Michel et al., this volume) and the extinction of Cretaceous foraminifers. The first occurrence of the nannofossil Biantholithus sparsus is at $72 \mathrm{~cm}$ (358.53 mbsf). 
inversus, and Thoracosphaera. The first true Danian species, Biantholithus sparsus, appears about $20 \mathrm{~cm}$ above the boundary in Sample 121-752B-11R-3, 72-73 cm. The LO of Cretaceous foraminifer species in Sample 121-752B-11R-3, 96-97 cm, is used to denote the boundary, which is in close agreement with the nannofossils. Samples immediately above the boundary are barren of foraminifers, thus, unfortunately, correlation of the earliest Danian nannofossil events with those of the foraminifers is not possible. The Cretaceous/Tertiary boundary, as determined by the calcareous microfossils, lies well within an interval of reversed polarity assigned to $\mathrm{C} 29 \mathrm{R}$, which is where it falls on the Berggren et al. (1985) scale and in other Cretaceous/Tertiary boundary sections considered to be continuous. In addition, Michel et al. (this volume) note an iridium peak in Sample 121-752B-11R-3, 94-95 cm, which also suggests that the sequence is complete despite the problems imposed by the drilling disturbance, as mentioned previously.

As reported in Peirce, Weissel, et al. (1989) and Rea et al. (1990), the prominent $6 \mathrm{~m}$ ash layer immediately above the boundary is not the result of a significant increase in ash supply, but of an enormous drop in carbonate sediment flux (opal flux also declined) associated with the collapse in calcareous microplankton productivity during the Cretaceous/Tertiary crisis. In this interval, an assemblage of low diversity that consists of opportunistic and "survivor" forms which thrived in the absence of strong competitors. Plankton productivity apparently remained low in the area of Broken Ridge for 0.5-1.5 m.y. following the terminal Cretaceous event(s), as predicted for the world's oceans by Smit (1982), Hsü, and MacKenzie (1985), and Zachos et al. (1989). In contrast to planktonic species, benthic foraminifer number/m.y. at Site 752 did not change as dramatically across the boundary. Only seven species disappeared, and the number/m.y. was not noted to decrease until an estimated $0.11 \mathrm{~m}$.y. after the Cretaceous/Tertiary event (Nomura, this volume). Elsewhere in the Southern Ocean, Thomas (1990a) also noted little change in benthic foraminiferal assemblages across the boundary.

\section{Cretaceous}

Upper Maestrichtian chalks were cored in Hole 752B until stratigraphic overlap was attained with the youngest Maestrichtian sediments previously recovered below the angular unconformity at Site 754 (Fig. 2). The $\sim 20 \mathrm{~m}$ of overlap was achieved with Cores 121-752B-18R and -19R, and the hole bottomed out at a depth of 435.6 mbsf in chalks of nannofossil Zone CC24, the foraminifer Gansserina gansseri Zone, and in an interval of reversed polarity assigned to $\mathrm{C} 31 \mathrm{R}$.

Chalks from the Cretaceous/Tertiary boundary to Sample 121752B-17R-3, 105-106 cm (416.65 mbsf), placed in the combined nannofossil Zones CC25-CC26, are characterized by the presence of Nephrolithus frequens and absence of Reinhardtites levis. The remaining section to the base of Core 121-752B-19R ( $435.6 \mathrm{mbsf}$ ) contains $R$. levis and is assigned to $\mathrm{CC} 24$. The section from the Cretaceous/Tertiary boundary down to Sample 121-752B-17R-1, $106-109 \mathrm{~cm}$ (413.69 mbsf), corresponding to nannofossil Zones $\mathrm{CC} 25-\mathrm{CC} 26$, is assigned to the foraminifer Abathomphalus mayaroensis Zone based on the FO of that species. The section below this level is assigned to the $G$. gansseri Zone based on the absence of A. mayaroensis.

The C29R/C30N boundary is placed at Sample 121-752B$12 \mathrm{R}-1,61 \mathrm{~cm}(365.01 \mathrm{mbsf})$, near to the top of the A. mayaroensis Zone and CC25-CC26. According to Gee et al. (this volume), discrete sample measurements from 385.0 to $400.0 \mathrm{mbsf}$ are of limited reliability as is the presence of an additional short reversed interval within $\mathrm{C} 30 \mathrm{~N}$. The boundaries of C30R could not be precisely determined with the top of C30R approximated at Sample 121-752B-14R-3, $66 \mathrm{~cm}$ (386.94 mbsf), and the C30R/C31N boundary near the base of Core 121-752B-14R, somewhere between 392.90 and 393.30 mbsf. The C31N/C31R boundary is placed at Sample 121-752B-15R-2, $115 \mathrm{~cm}$ (395.95 mbsf), although remanence data suggest the possible extension of $\mathrm{C} 31 \mathrm{~N}$ to $400.0 \mathrm{mbsf}$. The remaining section, down to the base of Hole 121-752B corresponds to $\mathrm{C} 31 \mathrm{R}$, as constrained by the presence of Zone CC24. In addition, this interval includes the $A$. mayaroensis/G. gansseri boundary, a correlation which is consistent with Berggren et al. (1985).

\section{Paleodepths}

Lower Miocene sediments contain the benthic foraminifers, Lenticulina spp. and Planulina costa, which are indicative of middle to upper bathyal depths. Above the angular unconformity, the assemblage of the upper Eocene, in Cores 121-752A-11 $\mathrm{H}$ and $-12 \mathrm{X}$, lacks the deeper water form, Nuttalides truempyi, but contains deep-water taxa such as Hanzawaia ammophila, Cibicidina walli, and Osangularia sp. of the upper bathyal $(200-600 \mathrm{~m})$ Osangularia sp. 1-H. ammophila assemblage (Fig. 5). The early Eocene paleodepths are estimated to be lower bathyal in the range of $1000-1500 \mathrm{~m}$ as indicated by $N$. truempyi, Alabamina dissonata, Turrilina brevispira, and Anomalinoides capitatus of the Cibicidoides subspiratus and A. capitatus/danicus assemblages (Fig. 5). Paleodepths for the Maestrichtian-Paleocene are estimated to be middle to lower bathyal or about $1000 \mathrm{~m}$ based on the presence of species such as Stensioina beccariiformis, Cibicidoides velascoensis, and Gyroidinoides globosus. This fauna comprises the $S$. beccariiformis and $C$. sp. cf. $C$. pseudoperlucidus assemblages (Fig. 5).

The most striking turnover in benthic foraminifer assemblages occurs in uppermost Paleocene sediments of nannofossil Zone CP8. This event is well correlated with a similar event noted at South Atlantic sites (Miller et al., 1987; Thomas, 1989, 1990a, 1990b; Katz and Miller, 1990). The faunal change occurs between the $S$. beccariiformis and A. capitatus/danicus assemblages (Fig. 5 ), and is estimated by Nomura (this volume) to be the result of an influx of warm, highly saline water from the shallow Tethyan region.

\section{SITE 753}

\section{(Fig. 7, Tables 7-8)}

Neogene sediments above the angular unconformity in Hole 753A consist of a thin sequence of nannofossil-foraminifer ooze $\sim 40 \mathrm{~m}$ thick. The dipping pre-rift sediments consist of nannofossil chalks, of which only a short section was cored. The original intent was to recover a continuous section which overlapped with Site 752 (Fig. 2) and, importantly, to sample the youngest sediments truncated by the angular unconformity. Drilling was prematurely terminated two cores below the unconformity at Hole $753 \mathrm{~A}$ due to mechanical failure of the piston coring device. An additional attempt to meet the objective of stratigraphic overlap was made with Hole 753B, but problems continued and the hole was abandoned after only a trace of sediment was recovered in Cores 121-753B-6X and -7X (80.9-100.2 mbsf). About $190 \mathrm{~m}$ of Eocene section remained uncored between the bottom of Holes $753 \mathrm{~A}-753 \mathrm{~B}$ and the upper portion to the dipping sequence at Site 752 . Fortunately, the goal of sampling the youngest pre-rift sediments was met with good recovery in Cores $121-753 \mathrm{~A}-6 \mathrm{H}$ and $-7 \mathrm{H}$.

Calcareous nannofossils are abundant and moderately well preserved in the cores from Hole 753A. Planktonic foraminifers are abundant and moderate to well preserved in samples above the unconformity at Site 753 but are less abundant in the Eocene sediments below. Planktonic foraminifer preservation is poor in Sample 121-753A-6H-CC, which in addition, contains fish teeth 

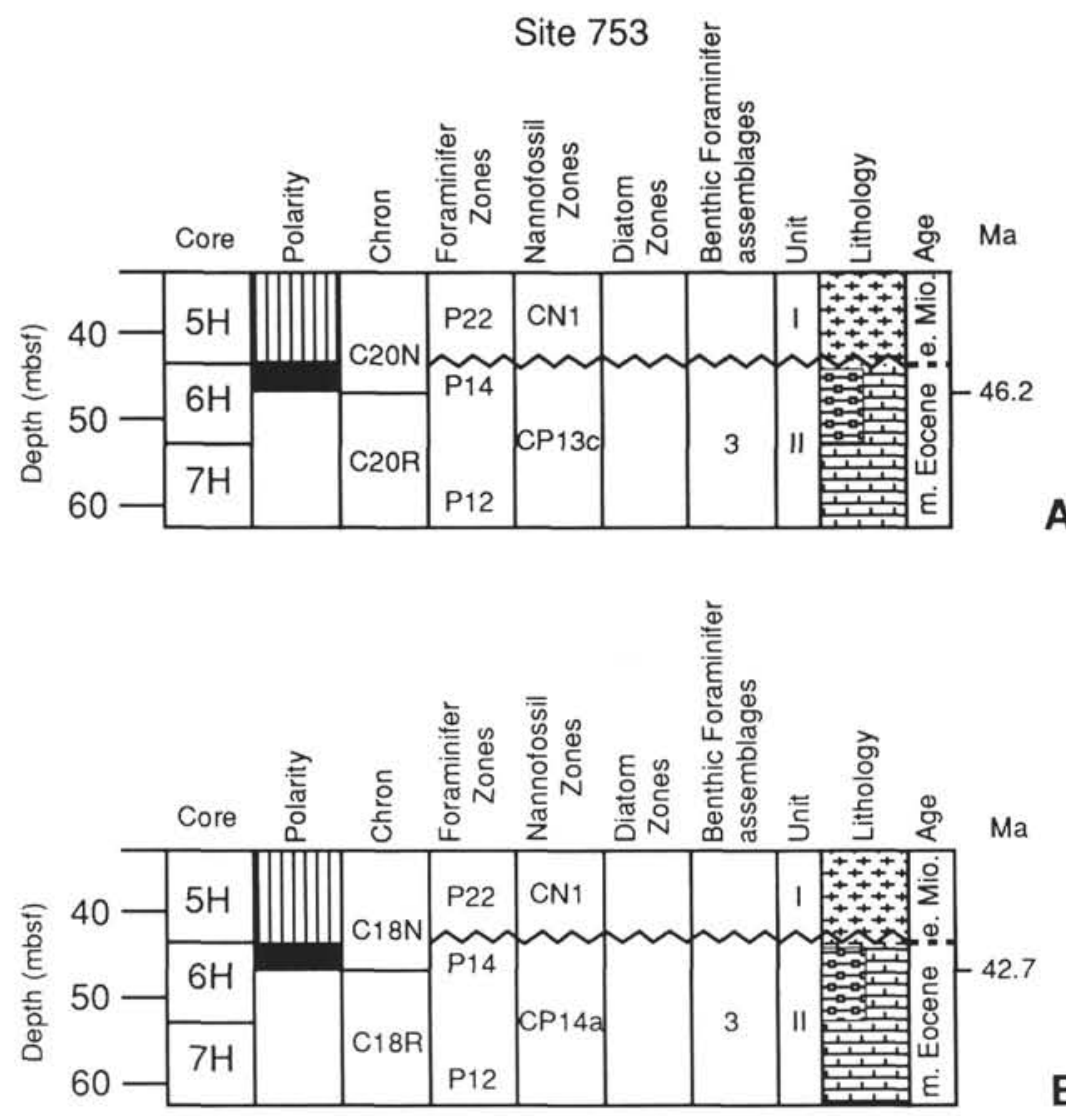

A

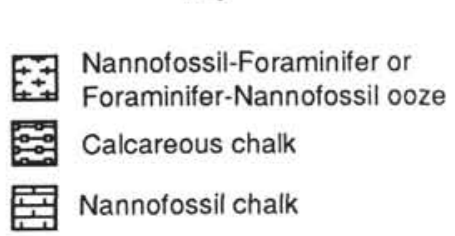

A

Normal polarity
$\square$ Reversed polarity
Indeterminate
polarity
No core recovery
Benthic foraminifer
assemblages

Figure 7. Lithologic and biomagnetostratigraphic summary of Hole 753A. Core recovery is represented in the same column as the polarity. A. Magnetic interpretation of Gee et al. (this volume) correlated with nannofossil Zone CP13c. B. Youngest interpretation for the polarity reversal in Core 121-753A-6H correlated with nannofossil Zone CP14a.

and sponge spicules. Benthic foraminifers are common and well preserved in middle Eocene sediments and diatoms are abundant and well preserved only in Cores $121-753 \mathrm{~A}-7 \mathrm{H},-753 \mathrm{~B}-6 \mathrm{X}$, and $-7 \mathrm{X}$.

\section{Biomagnetostratigraphy}

Sediments of Core 121-753A-5R immediately above the angular unconformity in Hole 753A are assigned to lower Miocene nannofossil Zone CN1 and upper Oligocene planktonic foraminifer Zone P22. Polarity is indeterminate at this level. Below, the youngest of the dipping pre-rift sediments of Core $121-753 \mathrm{~A}-6 \mathrm{H}$ is placed in the range of middle Eocene nannofossil Zones CP13cCP14a. However, CP13c seems more probable since the LO of Chiasmolithus gigas, which marks the top of CP13b, occurs in close proximity in Sample 121-753A-7H-1, 47-48 cm $(53.67$ mbsf). This species is also noted in the trace sediments of Cores 121-753B-5X, $-6 \mathrm{X}$, and $-7 \mathrm{X}$, thereby placing them in Subzone $\mathrm{CP} 13 \mathrm{~b}$. The foraminifer stratigraphy indicates that Cores 121$753 \mathrm{~A}-6 \mathrm{H}$ to $-7 \mathrm{H}$ belong to Zones $\mathrm{P} 12-\mathrm{P} 14$ based on the presence of Acarinina coalingensis, A. densa, Morozovella convexa, and Globigerina linaperta. The diatoms, Trinacria excavata forma tetragona, Triceratium kanayae, Skeletonema barbadense, and Rylandsia biradiata are indicative of a middle Eocene age for Cores 121-754A-7H, -753B-6X, and -7X.

Just below the unconformity, the sediments are of normal polarity down to Sample 121-753A-6H-2, $63 \mathrm{~cm}$ (45.73 mbsf), and reversed to the bottom of Hole 121-753A. This reversal boundary has been identified as the C20N/C20R transition by Gee et al. (this volume) based on correlation to nannofossil Subzone CP13c (Fig. 7A). However, considering that the base of foraminifer Zone P12 lies within C20N on the Berggren et al. (1985) scale, this reversal boundary could equally be assigned to Chron $\mathrm{C} 19$ or as young as $\mathrm{C} 18$ if the sediments belong to nannofossil Subzone CP14a or foraminifer Zone P13 (Fig. 7B).

As previously mentioned, an important objective of this site was to date the youngest dipping sediments truncated by the angular unconformity in order to more precisely constrain the timing of the rifting event on Broken Ridge. Using the reversal boundary near the top of Core $121-753 \mathrm{~A}-6 \mathrm{H}$ as the basis for absolute age correlation, a range of interpretations for time constraints for the initiation of rifting is possible. The C20N/C20R boundary dated at $46.17 \mathrm{Ma}$ is the oldest possibility to be considered, and the $\mathrm{C} 18 \mathrm{~N} / \mathrm{C} 18 \mathrm{R}$ boundary at $42.73 \mathrm{Ma}$, is the youngest possibility, a difference of almost $3.5 \mathrm{Ma}$. For the beginning of the post-rift stage, the oldest sediments above the unconformity are placed in nannofossil Subzone CP15b, which is assigned to the interval of 36.7-37.8 Ma (Berggren et al., 1985). Hence, exploring the extremes, approximately the longest duration for the rifting event, including uplift of at least $1 \mathrm{~km}$ and subsequent subsidence, is $\sim 9.5 \mathrm{~m} . \mathrm{y}$. and the shortest, $4.9 \mathrm{~m} . \mathrm{y}$. The longest duration can probably be eliminated from consideration. Anomaly 18 lies to the south of Broken Ridge, imposing further constraints on the duration of the rifting event and suggesting that a shorter duration is likely. The short duration favors a model for flexural uplift of Broken Ridge during rifting. Additional evidence is presented by a paleodepth analysis in the following section. 


\section{Paleodepths}

In addition to timing, the depth history of Broken Ridge is important to rifting models, in particular, flexural uplift as a mechanical response to lithospheric extension, as opposed to uplift as a thermal consequence. Mechanically induced uplift is favored by the determination that the middle Eocene pre-rift sediments were deposited in water depths of at least $1000 \mathrm{~m}$. Benthic foraminifers of the sediments below the angular unconformity in Cores $121-753 \mathrm{~A}-6 \mathrm{H}$ and $-7 \mathrm{H}$ are characteristic of lower bathyal depths (1000-1500 m) (Fig. 3), which indicates that there was no pre-rift shallowing of the Broken Ridge portion of the plateau as might be expected with a thermal event (Weissel et al., 1988, Weissel and Karner, 1989). The benthic fauna, dominated by Nuttalides truempyi along with common Cibicidoides spp. and Anomalinoides capitatus, is of the A. capitatus/danicus Assemblage of Nomura (this volume) (Fig. 7).

\section{Site 754}

\section{(Fig. 8, Tables 7-8)}

Site 754 was selected to core the thickest portion of the pelagic sediments immediately overlying the unconformity on Broken Ridge (Fig. 2) and to sample the oldest material deposited above the truncated surface. Two lithologic units were recognized (Fig. $8)$. Unit I (0.0-132.0 mbsf) is a Pleistocene to upper Eocene foraminifer nannofossil ooze, and Unit II (151.0-354.7 mbsf) is predominantly Maestrichtian calcareous chalk and limestone with chert. Difficulty was again encountered in the recovery of the unconsolidated gravel and sands immediately above the erosional surface as Cores 121-754A-15X and -16X came up empty.

Calcareous nannofossils are abundant and moderately well preserved in Paleogene sediments of Site 754. In the Cretaceous sediments, preservation is moderate to poor and nannofossils are generally few to common, but rare to absent in a few samples near the base of Hole 754B. Planktonic foraminifers are abundant and well preserved in Miocene and Oligocene samples, but preservation decreases to very poor in the Eocene sediments above the angular unconformity. Cretaceous planktonic foraminifers are rare to few and exhibit poor to very poor preservation. Samples of Cores 121-754B-21R to -24R are barren of planktonic foraminifers. Benthic foraminifers are common and well preserved in the Oligocene but poorly to moderately preserved in the upper Eocene. Cretaceous forms are more abundant and poorly to moderately preserved.

Other fossils include abundant Inoceramus prisms in the upper part of the Cretaceous down to Sample 121-754B-10R-CC (van Eijden and Smit, this volume). Also, the presence of opal-CT in the Maestrichtian sediments at this site and at Site 754 is indicative of high siliceous microplankton productivity at this time.

\section{Biomagnetostratigraphy}

The Miocene/Oligocene (CN1/CP19b) boundary as delimited by nannofossils is marked by the LO of Sphenolithus ciperoensis in Sample 121-754A-13X-1, 47-48 cm (112.77 mbsf). Subzone $\mathrm{CP} 19 \mathrm{~b}$ is recognized down to Sample 121-754A-13X-3, 47-48 $\mathrm{cm}$, based on the presence of $S$. ciperoensis and the absence of $S$. distentus, while sediments assigned to CP18 contain $S$. distentus and are present down to Sample 121-754A-13X-CC (122.0 mbsf). Nannofossil Subzone CP19a was not formally identified. Foraminifer stratigraphy assigns the Miocene/Oligocene Zones $\mathrm{P} 22 / \mathrm{N} 4$ to Samples $121-754 \mathrm{~A}-11 \mathrm{H}-\mathrm{CC}$ and $-12 \mathrm{H}-3,110-113 \mathrm{~cm}$, as indicated by the presence of Globoquadrina dehiscens in Sample 121-754A-11H-CC (102.6 mbsf). Sediments of upper Oligocene Zone P22 are present down to Sample 121-754A-12H-3, $110-115 \mathrm{~cm}$, with the remainder of Core $121-754 \mathrm{~A}-12 \mathrm{H}$ to Core
121-754A-13X assigned to P21-P20. Sample 121-754A-13X-CC is placed in the lower Oligocene Zone P20 based on the co-occurrence of Jenkinsella opima and Turborotalia increbescens. This assignment is in good agreement with the nannofossil zonation. Polarity is indeterminate through Core 121-754A-14X.

As at Site 752, an Oligocene hiatus is noted at Site 754, however it encompasses a slightly different interval. The nannofossil stratigraphy indicates that this hiatus lies between Samples 121-754A-13X-CC and -14X, $5 \mathrm{~cm}$ (shipboard data), or at about 122.0 mbsf. Lower Oligocene Zone CP18 overlies upper Eocene Subzone CP15b, which is assigned to Core 121-754A-14X. Lower Oligocene Zones CP16 and CP17 are absent at Site 754, whereas Zones CP16b-19 are not present at Site 752. This hiatus, as dated by foraminifers, encompasses Zones P15-P19 with Zone P20 directly overlying middle Eocene Zone P14.

Also, as at Site 752, a slight discrepancy exists between nannofossil and foraminifer age assignments for Core 121-754A-14X immediately below the Oligocene unconformity. The nannofossils suggest uppermost Eocene Zone CP15b based on the presence of Isthmolithus recurvus, whose FO marks the base of this subzone and the LO of Discoaster saipanensis which marks the top. Reworked middle Eocene nannofossils are common in samples from Core 121-754A-14X, which overlies the unrecovered sand-gravel layer of the prominent erosional surface. The presence of the foraminifers Acarinina densa, Globigerina linaperta, Globigerinatheka index, and Truncorotaloides rohri in this core are indicative of middle Eocene Zones P13-P14 and possibly P12. These zones would normally correlate with nannofossil Zones CP13c-CP14. The reasons for this disagreement are probably similar to those discussed for Site 752. However, since Core 121-754A-14X lies above the gravel layer, younger nannofossils displaced downward by downhole caving is less likely to have occurred, thus reworking of middle Eocene forms seems more probable.

There was no recovery in Cores 121-754A-15X and -16X $(\sim 130-150 \mathrm{mbsf})$ at the depth of the sand and gravel layer. Hole $754 \mathrm{~B}$ was washed down to approximately that level, and Core 121-754B-2R recovered about $35 \mathrm{~cm}$ of the unconsolidated sand and gravel. A mixed assemblage of middle to uppermost Eocene nannofossils was noted in this core.

Immediately below the angular unconformity, the chalks of Core 121-754B-5R to Sample 121-754B-11R-1, 47-48 cm (210.07 mbsf), are assigned to lower Maestrichtian nannofossil Zone CC24. These sediments lack Nephrolithus frequens and are above the LO of Tranolithus phacelosus in Sample 121-754B 11R-CC (219.2 mbsf). The section from this level to the base of Hole 754B in Core 121-754B-25R (354.7 mbsf) is placed in lowermost Maestrichtian Subzone CC23b based on the presence of $T$. phacelosus and the absence of diagnostic Campanian nannofossils such as Aspidolithus parcus and Eiffelithus eximius.

The foraminifer Abathomphalus mayaroensis first occurs in Sample 121-754B-5R-CC and is indicative of the upper Maestrichtian A. mayaroensis Zone. Sediments below this are not zoned by the foraminifers due to lack of marker species. The Campanian/Maestrichtian boundary is tentatively placed in Core 121-754B-11R based on the presence of common Heterohelix punctulata in Sections 121-754B-11R-CC, -12-CC, and -13-CC.

According to Gee et al. (this volume), the magnetostratigraphy of Hole 754B relies primarily on the biostratigraphically determined overlap of about $20 \mathrm{~m}$ with Hole $752 \mathrm{~B}$ and the early Maestrichtian nannofossil age assignment of the base of Hole 754B. A normal interval about $3.2 \mathrm{~m}$ thick just below the unconformity is interpreted as the result of remagnetization and the underlying reversed interval is assigned to C31R. The C31R/ C32N-1 boundary is placed at Sample 121-754B-7R-4, $29 \mathrm{~cm}$ ( $175.79 \mathrm{mbsf}$ ), and the C32N-1/C32R-1 boundary at Sample 


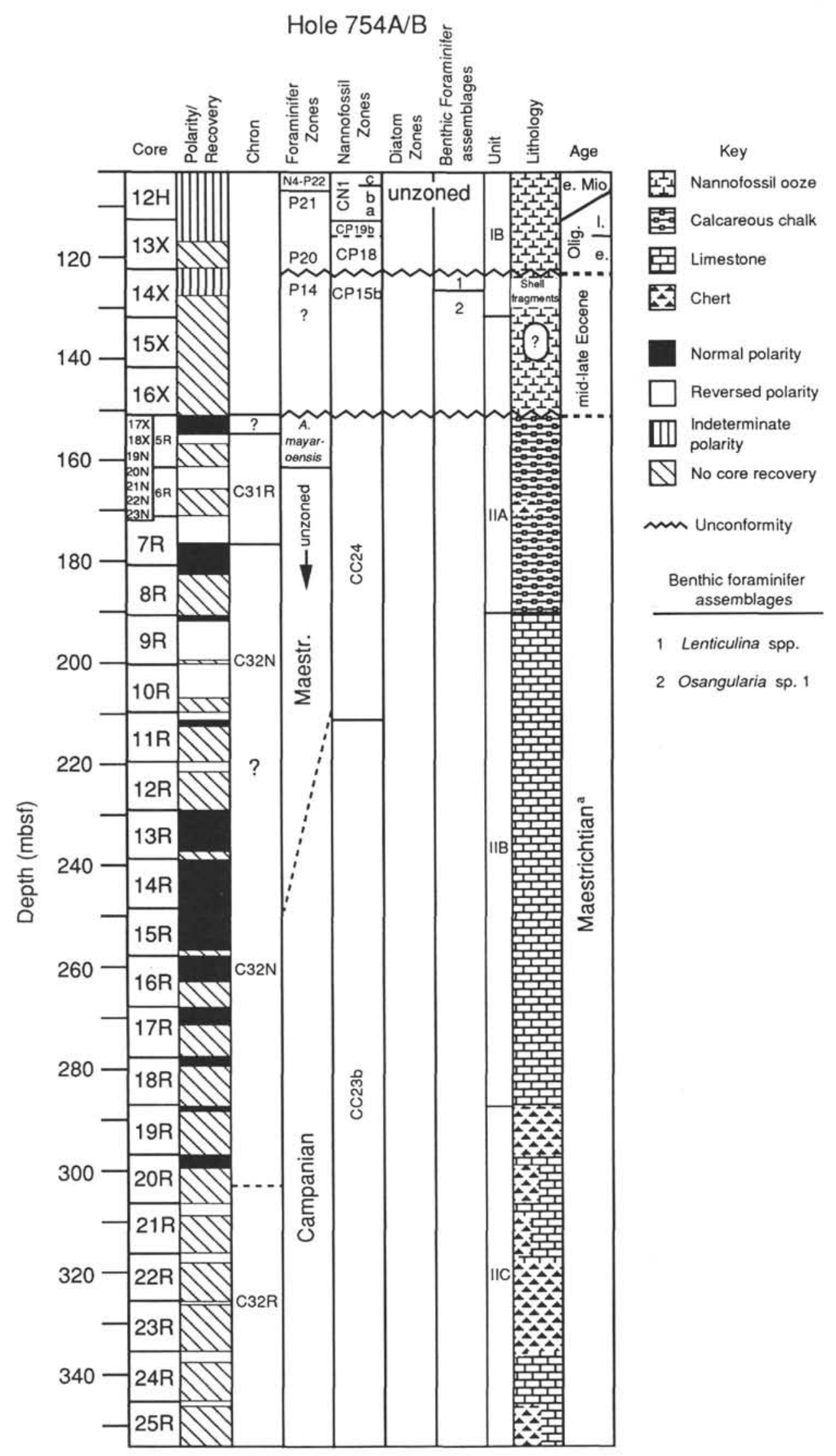

Figure 8. Lithologic and biomagnetostratigraphic summary of Holes 754A-754B. Core recovery is represented in the same column as the polarity. 
121-754B-9R-1, $17 \mathrm{~cm}(190.47 \mathrm{mbsf})$. The top of C32N-2 at Sample 121-754B-11R-1, $123 \mathrm{~cm}$ (210.83 mbsf), lies near the nannofossil CC24/CC23b boundary and where foraminifer stratigraphy places the Campanian/Maestrichtian boundary. The base of C32N-2 is placed in Core 121-754B-20R $(\sim 299.30-306.30$ mbsf), and sediments to the base of Hole 754B are assigned to C32R-2 and nannofossil Subzone CC23b.

\section{Paleodepths}

The upper Eocene coarse grained sands immediately above the angular unconformity in Core 121-754B-2R contain the shallowwater benthic foraminifer Amphistegina, ostracodes, and bryozoan fragments. However, the high degree of abrasion of these fossils suggests that they have been reworked or transported some distance. Deeper water benthic foraminifer species in this core and in Core 121-754A-14X are better preserved and indicate that deposition occurred in upper bathyal depths (200-600 m) (Fig. 3). This benthic fauna comprises the Osangularia sp. 1-Hanzawaia ammophila Assemblage of Nomura (this volume).

\section{SITE 755}

\section{(Fig. 9, Tables 7-8)}

At Site $755,4 \mathrm{~km}$ north of the south-facing escarpment of Broken Ridge, the oldest portion of the dipping sedimentary section was cored to a depth of 208 mbsf before drilling was terminated due to time constraints (Fig. 2). Approximately $450 \mathrm{~m}$ of section remained uncored between the base of Hole 754B and the top of the Cretaceous section of Hole 755A. No Paleogene sediments were recovered above the unconformity at this site as middle Miocene foraminifer-nannofossil oozes of lithologic Unit I overly Turonian to Santonian limestone and tuff of Unit II (Fig. 9). Lithologic Unit II is further divided into three subunits, IIA, IIB, and IIC. Subunit IIA of Cores 121-755A-5R to -12R (65.5$140.8 \mathrm{mbsf}$ ) consists of tuff and ashy limestone. Subunit IIB from Cores $121-755 \mathrm{~A}-13 \mathrm{R}$ to $-17 \mathrm{R}(140.8-189.0 \mathrm{mbsf})$ is a tuff with glauconite and micrite, and Subunit IIC of Cores 121-755A-18R and $-19 \mathrm{R}$ (189.0-208.0 mbsf), is a tuff with micrite.

In the Cretaceous tuffs of Site 755, planktonic foraminiferal preservation is generally very poor, and specimens are low in numbers with some samples being barren. Calcareous nannofossils, for the most part, exhibit poor to moderate preservation and are rare to few and common in only a few samples. Benthic foraminifers are few and poorly preserved in Cretaceous samples of Site 755, and diatoms are not preserved. Rare and poorly preserved radiolarians and sponge spicules are present in Cretaceous sediments in addition to Inoceramus prisms, fish debris, and echinoid spines.

Because of the scarcity and poor preservation of calcareous microfossils, in addition to the high paleolatitude of Site 755 during the Late Cretaceous, age and zonal assignments were not determined with high confidence. Furthermore, magnetostratigraphy is not helpful as all sediments below the unconformity lie within the Cretaceous quiet zone, C34N.

\section{Biomagnetostratigraphy}

Sediments of Core 121-755A-5R, immediately below the unconformity to Sample 121-755A-7R-CC (91.5 mbsf) at Site 755, are assigned to nannofossil Zone CC16 of the upper Santonian. The CC15/CC14 boundary of the lower Santonian-upper Coniacian is placed between Samples 121-755A-10R-1, 38-39 cm, and $-10 \mathrm{R}-2,43-44 \mathrm{~cm}$ (112.1 mbsf), and the base of CC14 (Coniacian) is located at $121-755 \mathrm{~A}-12 \mathrm{R}-\mathrm{CC}$ (140.8 mbsf). The remaining section through Core $121-755 \mathrm{~A}-19 \mathrm{R}$ is assigned to nannofossil Zone CC12 of the Turonian.
Due to the absence of diagnostic marker species, the Cretaceous sediments at this site could not be zoned in detail by planktonic foraminifers. The section from Core $121-755 \mathrm{~A}-5 \mathrm{R}$ to Sample 121-755A-11R-1, 65-68 cm, is assigned to the upper Turonian-Coniacian based on the presence of Marginotruncana marginata and M. pseudolinneiana. Samples 121-755A-13R-4, 16-19 cm, to -17R-3, 114-119 cm (145.47-183.45 mbsf), contain Dicarinella canaliculata, D. hagni, D. imbricata, D. primitiva, and Whiteinella baltica, which suggest an early to middle Turonian age for the interval. An age of Santonian for the topmost Cretaceous cores of this site was noted in Peirce, Weissel, et al. (1989) but further shore-based analysis of planktonic foraminifers does not concur with this shipboard age assignment.

The discrepancy in age assignments between nannofossils and foraminifers for the sediments directly below the unconformity is probably best attributed to the lack of abundant specimens combined with the absence of age diagnostic forms due to the high latitude position of Broken Ridge $\left(50^{\circ}-55^{\circ} \mathrm{S}\right)$ during the Cretaceous. The poor preservation of the planktonic foraminifers has most likely further contributed to the problems encountered in zoning these sediments.

\section{Paleodepths}

The benthic foraminifer information for Site 755 is taken from Peirce, Weissel, et al. (1989). Cretaceous assemblages include Gavelinella spp., Allomorphina, Ellipsoidella, and Lenticulina and lack typical deep-water forms, which suggests deposition at upper bathyal depths during the Turonian to Santonian (Fig. 3).

\section{SEDIMENTATION RATES}

The biostratigraphic and magnetostratigraphic data are presented in Tables 2-8 and are graphically depicted in the age/depth plots of Figures 10-17. The ages for zonal boundaries follow Berggren et al. (1985) and Kent and Gradstein (1985). Age was plotted vs. the midpoint sub-bottom depth between samples which constrain the zonal boundaries. The distance between these samples defines the upper and lower limits of uncertainty or the depth error. The sample intervals and midpoint depths are given in Tables 2-8. Error bars are not shown in Figures 10-17, but in most cases, the uncertainty interval does not exceed more than 1.5$2.0 \mathrm{~m}$.

The microfossil groups are in good agreement for the Paleocene of Site 752. Some minor disagreements exist between the nannofossil and foraminifer models in the Eocene, at the Cretaceous/Tertiary boundary, and for the Upper Cretaceous of Site 755 .

\section{Cretaceous}

Because of the lack of marker species and poor preservation, a foraminifer age model for the Cretaceous of Site 755 could not be constructed nor could an age model based on the magnetostratigraphy be calculated as all Cretaceous sediments of this site are of the quiet zone (C34N). Only three nannofossil datums are used, which unfortunately, are not well tied to any absolute age time scale. Hence the sedimentation rate values for Turonian-Santonian are regarded as crude estimates. A more accurate age model is constructed for the Campanian?-upper Maestrichtian of Sites 752 and 754 , which provide a reliable magnetostratigraphy combined with a few biostratigraphic markers.

The nannofossil age model of Site 755 as shown in Figure 10 (Table 7) suggests sedimentation rates of $\sim 2.47 \mathrm{~cm} / \mathrm{k} . \mathrm{y}$. for the Turonian through Santonian. Sedimentation rates apparently increased through the time of deposition of the estimated $490 \mathrm{~m}$ of undrilled section between the base of Hole 754B and the top of Hole 755A. The uncored section, which corresponds to the Cam- 


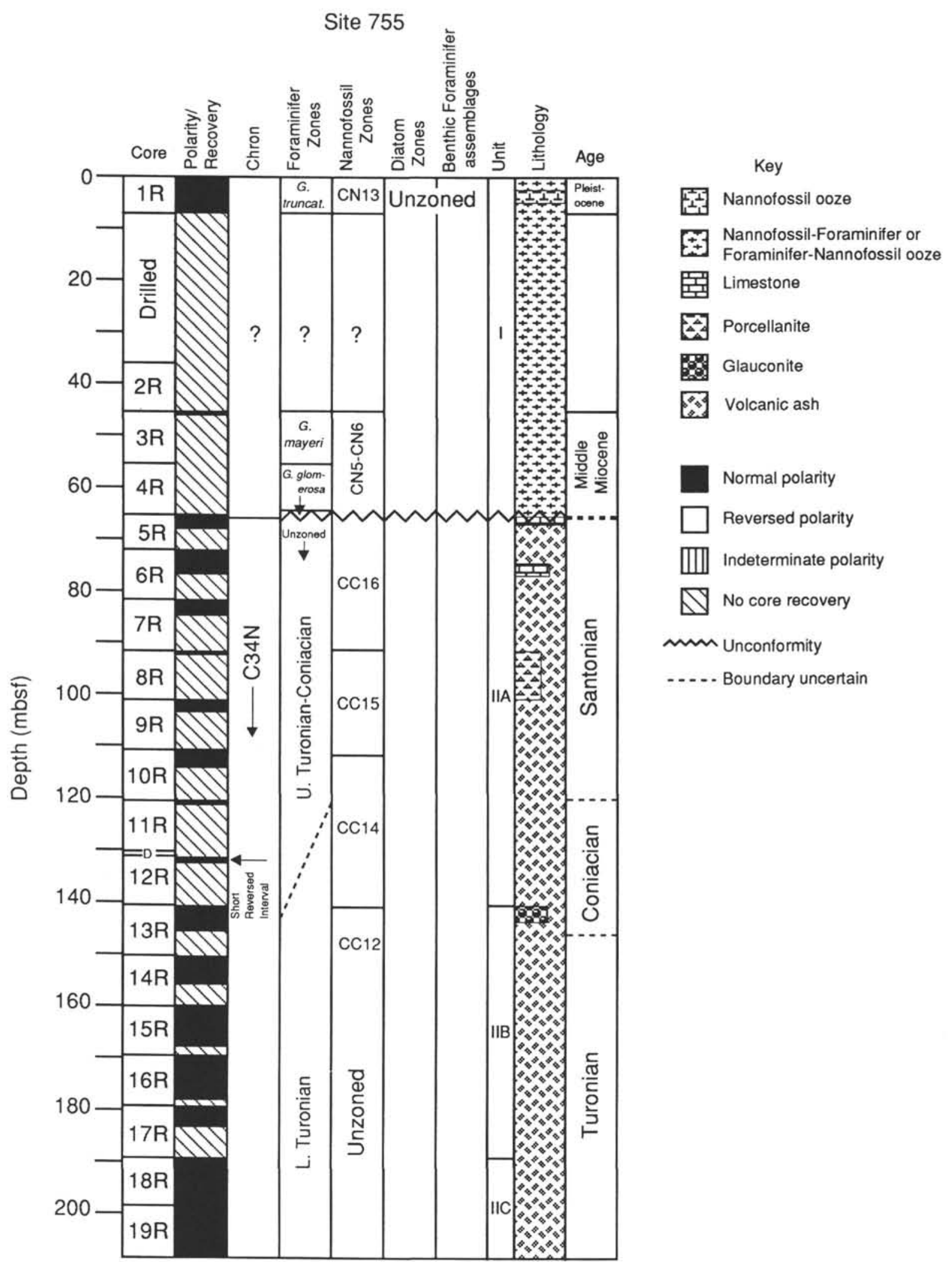

Figure 9. Lithologic and biomagnetostratigraphic summary of Site 755. Core recovery is represented in the same column as the polarity. 


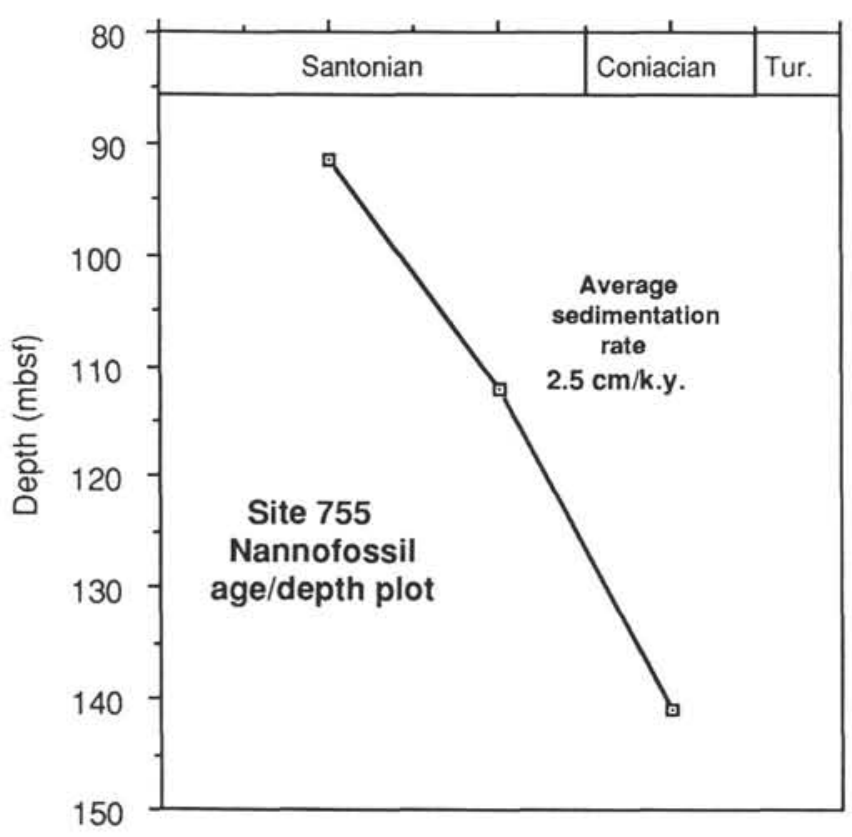

Figure 10. Age-depth plot based on nannofossil data (Table 8) for Cretaceous sediments of Site 755 (Cores 121-755A-5R to -19R).

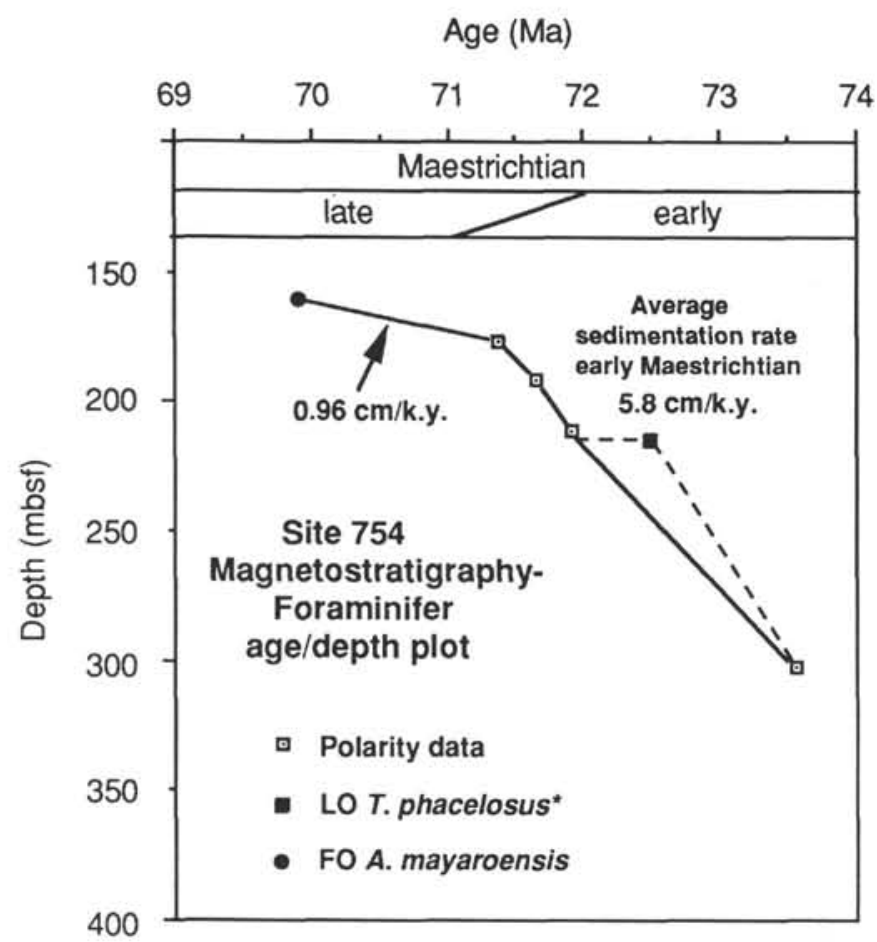

Figure 11. Age-depth plot based on magnetostratigraphic and foraminifer data (Tables 7-8) for the Maestrichtian of Site 754 (Cores 121-754B-5R to -25R). The age of the last occurrence (LO) of Tranolithus phacelosus roughly correlated with the time scale of Kent and Gradstein (1985) is estimated at $72.5 \mathrm{Ma}$. However, this estimation can be adjusted to $\sim 72.0 \mathrm{Ma}$ as predicted by the age model as shown.

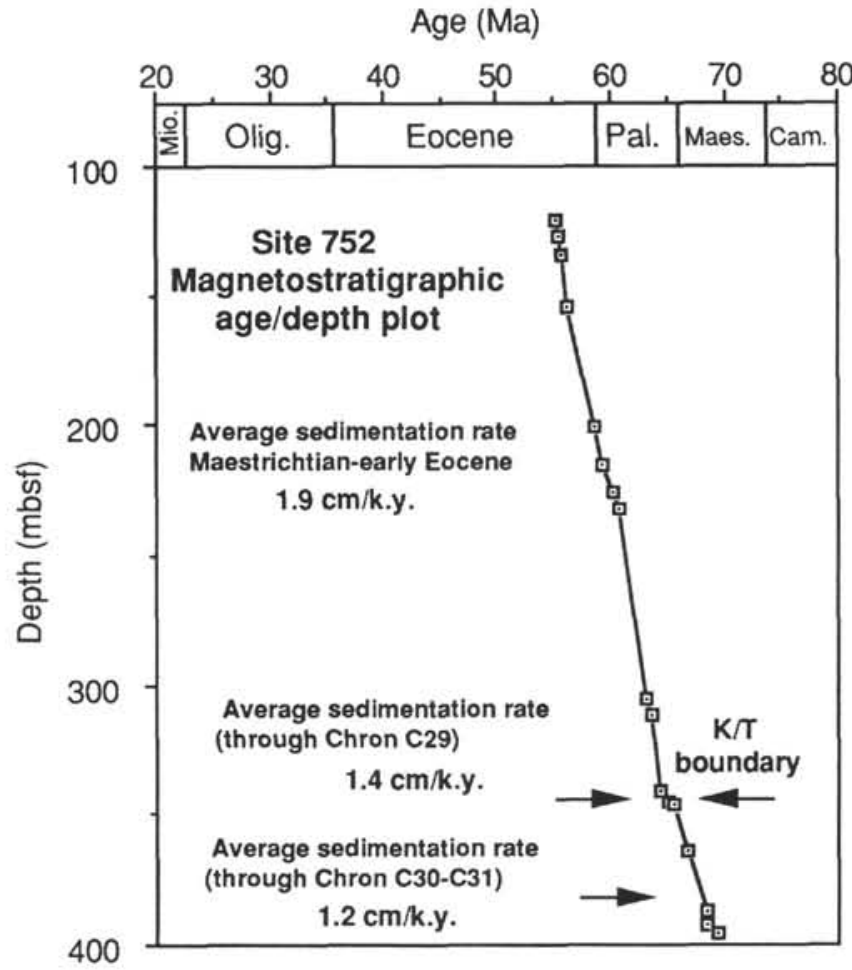

Figure 12. Age-depth plot based on magnetostratigraphic data (Table 6) for the uppermost Maestrichtian-lower Eocene of Holes 752A and 752B (Cores 121-752A-13X to -752B-19R).

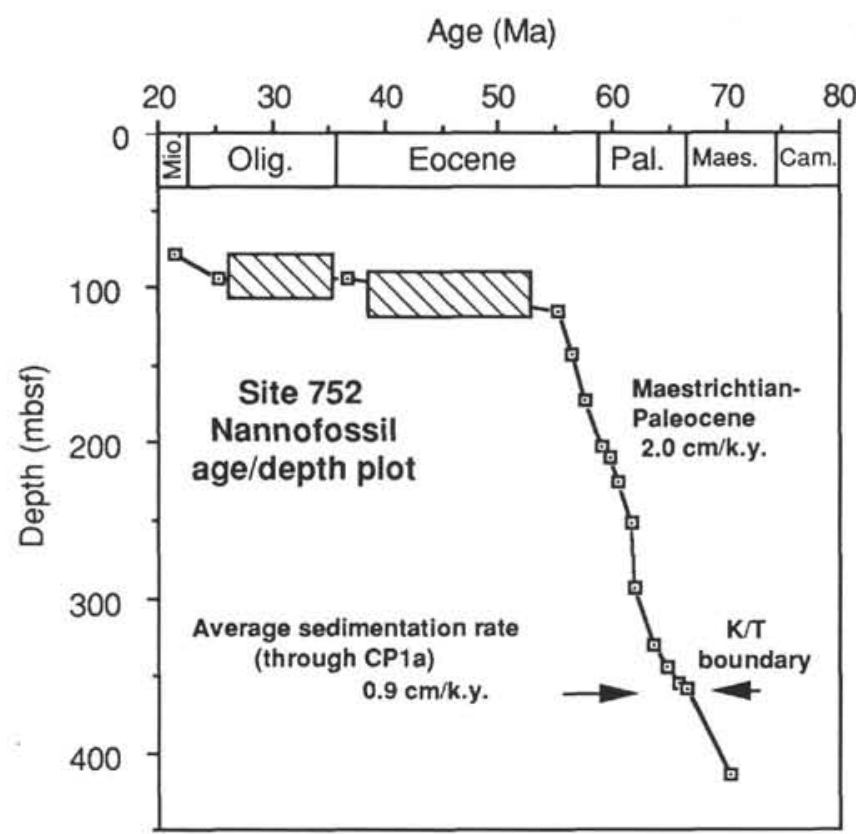

Figure 13. Age-depth plot based on nannofossil data (Table 3 ) for the uppermost Maestrichtian-lower Miocene of Holes 752A and 752B (Cores 121-752A-9H to -752B-19R). Striped boxes denote unconformities. 


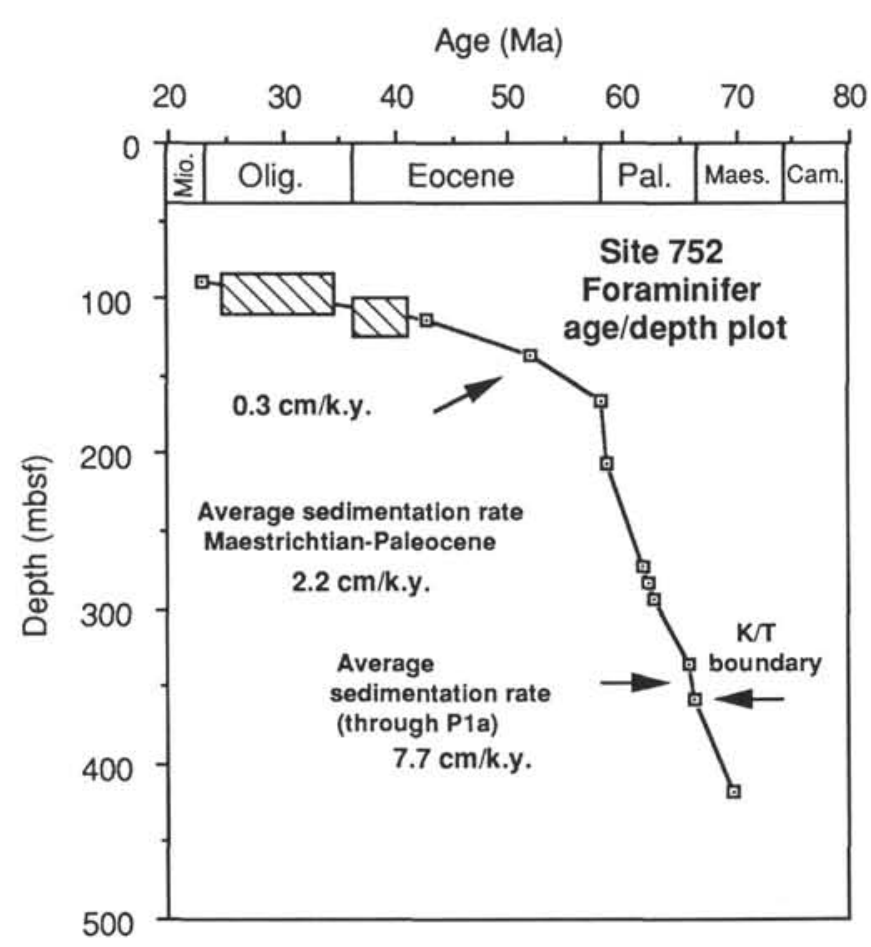

Figure 14. Age-depth plot based on foraminifer data (Table 4) for the uppermost Maestrichtian-lower Miocene of Holes 752A and 752B (Cores 121-752A-10H to $-752 \mathrm{~B}-19 \mathrm{R})$. Striped boxes denote unconformities.

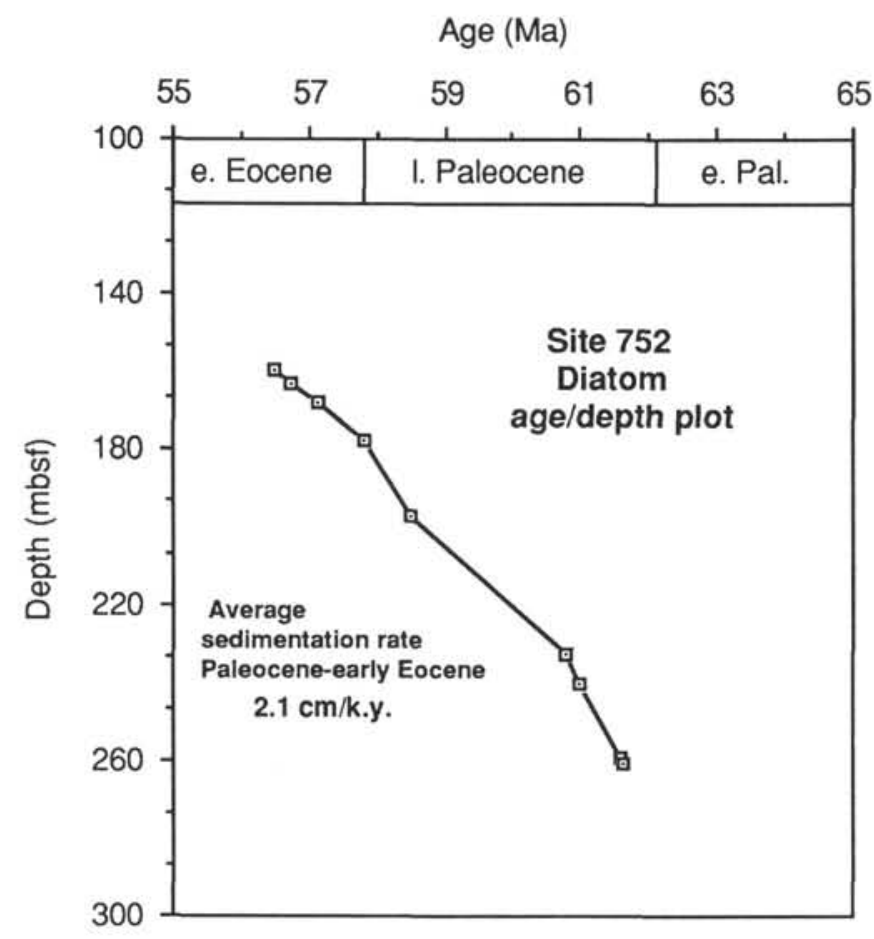

Figure 15. Age-depth plot based on diatom data (Table 5) for the Paleocenelower Eocene of Hole 752A (Cores 121-752A-17X to -30X).

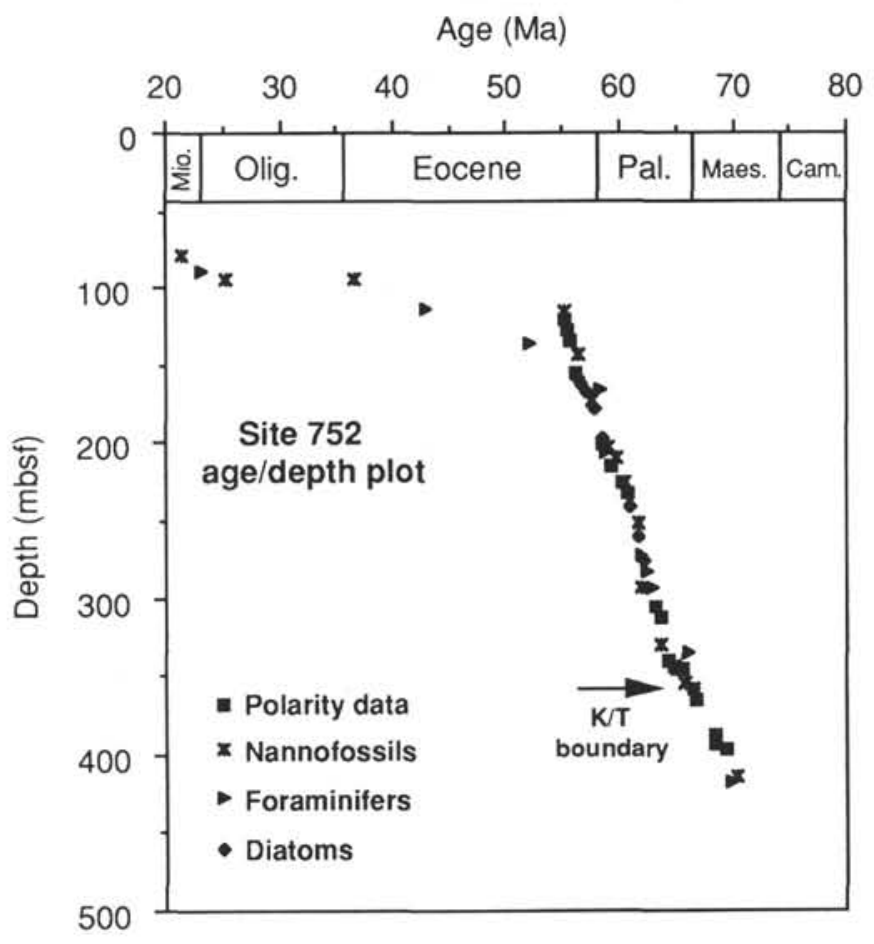

Figure 16. Summary age-depth plot of magnetostratigraphic and biostratigraphic data (Tables 3-6) for the uppermost Maestrichtian-lower Miocene of Holes $752 \mathrm{~A}$ and $752 \mathrm{~B}$ (Cores 121-752A-9H to -752B-19R).

panian and (upper) Santonian (Site 255; Davies, Luyendyk, et al., 1974) (Chron C33) as suggested by the nannofossil and magnetostratigraphy, exhibits a sedimentation rate on the order of $\sim 5.0$ $\mathrm{cm} / \mathrm{k} . \mathrm{y}$.. This interpretation results in fairly consistent linear sedimentation rates with the Maestrichtian of Site 754, where rates are calculated at $5.8 \mathrm{~cm} / \mathrm{k} . y$. (Fig. 11).

The foraminifer stratigraphy differs on the age interpretation of the Cretaceous sediments of Site 755. Van Eijden and Smit (this volume) place the interval assigned to the Coniacian-Santonian by nannofossils to the upper Turonian-Coniacian with the base of the hole assigned to the lower Turonian (Fig. 9). This interpretation yields sedimentation rates at most on the order of 4.5-5.0 $\mathrm{cm} / \mathrm{k}$.y., which is similar to Campanian-Maestrichtian rates calculated with the magnetostratigraphic data and would suggest fairly uniform sedimentation rates from the Turonian through at least the middle Maestrichtian.

Additional disparity exists between nannofossils and foraminifers on the age assignment of the Upper Cretaceous sediments of Hole 754B. Although no formal foraminifer zones are assigned, van Eijden and Smit (this volume) place the lower $\sim 250 \mathrm{~m}$ of Hole $754 \mathrm{~B}$ in the Campanian, whereas Resiwati (this volume) suggests that no Campanian was cored (Fig. 8). The Campanian age assignment by foraminifers would require a readjustment of the magnetostratigraphy. Chron $\mathrm{C} 32 \mathrm{~N}-2$ as assigned here would be changed to C33N following Kent and Gradstein (1985). The uppermost reversed interval assigned here to $\mathrm{C} 31 \mathrm{R}$ would not necessarily need to be adjusted based on correlation with the FO of Abathomphalus mayaroensis, and the intervening normal-reversed pattern could then be correlated to $\mathrm{C} 32$. With this interpretation, the sedimentation rates for the Maestrichtian of Site 754 are around $1.6 \mathrm{~cm} / \mathrm{k} . \mathrm{y}$., which is much lower than the value of 5.8 $\mathrm{cm} / \mathrm{k} . \mathrm{y}$. calculated in the original interpretations cited previously (Fig. 11). 

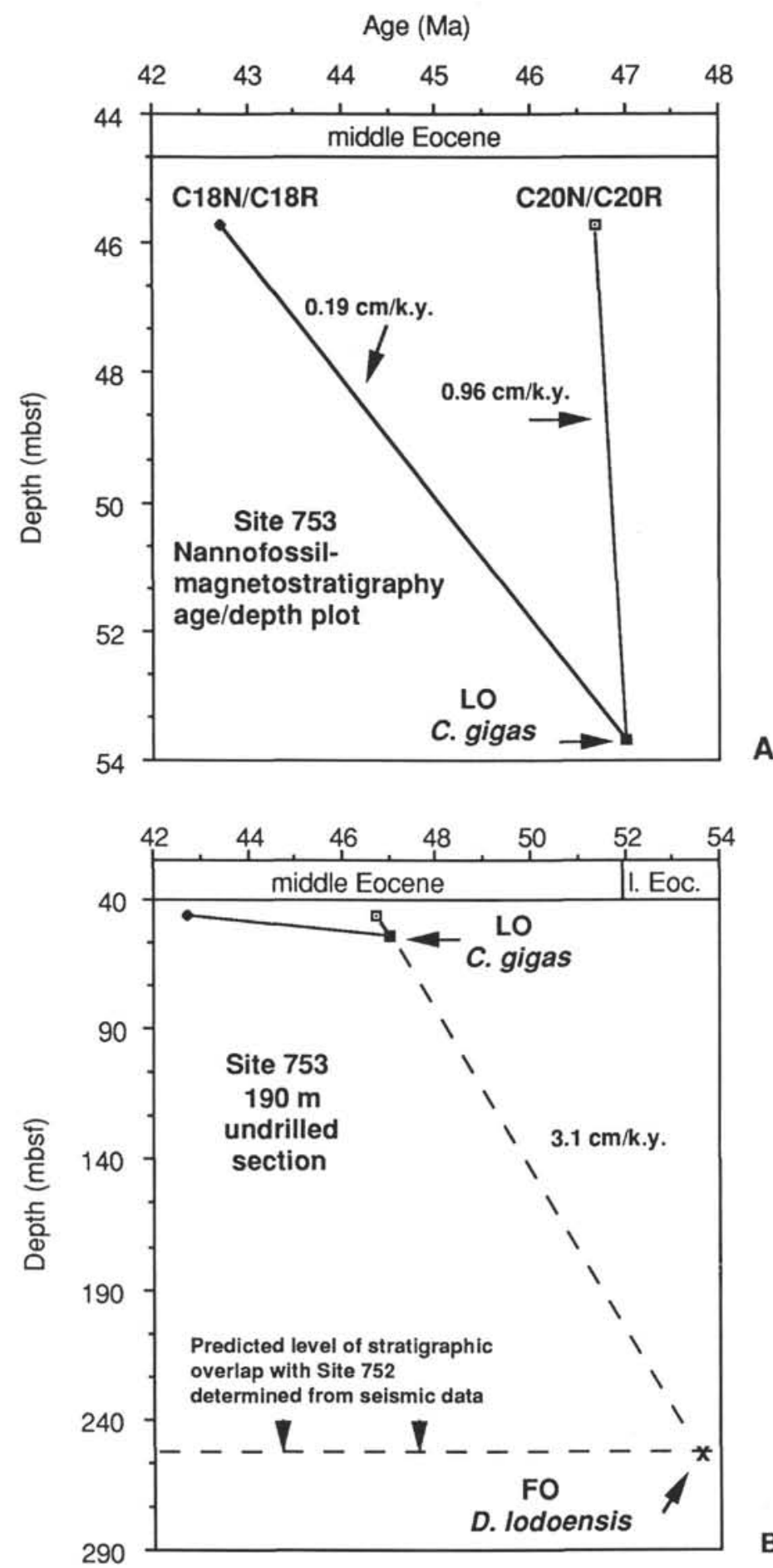

Figure 17. A. Age-depth plot of magnetostratigraphic and nannofossil data (Tables 7-8) for the middle Eocene of Hole 753A. The two age interpretations for the reversal boundary of Core 121-753A-6H are shown. B. Extrapolation of sedimentation rates down through $190 \mathrm{~m}$ of uncored section of Site 753 to predicted level of stratigraphic overlap with Site 752 determined from seismic data (Fig. 2).

\section{Cretaceous/Tertiary Boundary}

Sedimentation rates appear to have dropped off in the latest Maestrichtian. At Site 752, the sedimentation rate for the uppermost Maestrichtian is on the order of $1.2 \mathrm{~cm} / \mathrm{k} . \mathrm{y}$. through the interval from the top of $\mathrm{C} 30 \mathrm{~N}$ to the base of $\mathrm{C} 31 \mathrm{~N}$ (Fig. 12). At the Cretaceous/Tertiary boundary, the sedimentation rate drops to $0.9 \mathrm{~cm} / \mathrm{k} . y$. through the initial Danian nannofossil Subzone CP1a (Fig. 13). Conversely, the foraminifer age/depth curve suggests that sedimentation rates were higher in the initial Danian subzone 
P1a than the rates calculated for the Maestrichtian and Paleocene. As shown in Figure 14, a rate of $7.7 \mathrm{~cm} / \mathrm{k}$.y. is calculated for this interval. This anomalous value can be attributed to a high degree of uncertainty in planktonic foraminifer age estimates associated with the preservational problems and barren samples encountered immediately above the boundary. Although sedimentation rates are relatively high by deep-sea Cretaceous/Tertiary boundary standards at this site because of a constant supply of volcanic ash (Peirce, Weissel, et al., 1989; Rea et al., 1990), it is not likely that rates were higher than for the preceding or succeeding time intervals. As noted by Rea et al. (1990), the calcium carbonate flux rate drops dramatically across the boundary with only a slight increase in ash flux.

\section{Paleocene-Eocene}

Fairly uniform sedimentation rates are noted for the Paleocene and early Eocene before accumulation was disrupted by uplift. For this interval the sedimentation rate curves for each of the microfossil groups and the polarity data (Figs. 12-15) are in good agreement as shown in the summary diagram (Fig. 16). An average sedimentation rate for the Paleocene-lower Eocene of around $2.0 \mathrm{~cm} / \mathrm{k} . \mathrm{y}$ is fairly high, which is consistent with high productivity as indicated by the presence of the siliceous microfossils. The major unconformities (middle Eocene and Oligocene) at Site 752 are indicated in Figures $12-16$ by the complete reduction in sedimentation rates. The age/depth plots constructed from foraminifer and nannofossil data differ slightly for the lower-middle Eocene (Fig. 16).

The oldest sediments below the angular unconformity were cored at Site 753 and a simple age/depth plot is presented in Figure 17, which combines the magnetostratigraphic and nannofossil data. As discussed in the preceding sections, more than one interpretation of the magnetic reversal in Core $121-753 \mathrm{~A}-6 \mathrm{H}$ is possible (Fig. 7) and the construction of an age/depth plot permits further evaluation of these possibilities. Figure 17A represents the two sedimentation rate curves calculated for the interpretation that the polarity reversal is either the $\mathrm{C} 18 \mathrm{~N} / \mathrm{C} 18 \mathrm{R}$ or $\mathrm{C} 20 \mathrm{~N} / \mathrm{C} 20 \mathrm{R}$ transition. Figure 17B represents the extrapolation through the estimated $190 \mathrm{~m}$ of uncored sediment to the predicted level of stratigraphic overlap with the topmost lower Eocene sediments of Site 752. The sedimentation rates calculated between the LO of Chiasmolithus gigas data point and the reversal data point if assigned to Chron C18 is $\sim 0.19 \mathrm{~cm} / \mathrm{k} . \mathrm{y}$., and $\sim 0.96 \mathrm{~cm} / \mathrm{k} . \mathrm{y}$. if the reversal is assigned to Chron C20 (Figure 17A). It is apparent in Figure 17B that the higher rate of $0.96 \mathrm{~cm} / \mathrm{k} . \mathrm{y}$. is more consistent with rates predicted for the uncored lower-middle Eocene interval and with those of the lower Eocene-Paleocene of Site 752, thus indicating that the assignment of the reversed interval in Core $121-753 \mathrm{~A}-6 \mathrm{H}$ to the $\mathrm{C} 20 \mathrm{~N} / \mathrm{C} 20 \mathrm{R}$ boundary may be more accurate. It is also apparent that, overall, sedimentation rates did decline through the Eocene as compared with the higher values of the Paleocene.

\section{SUMMARY AND CONCLUSIONS}

The sedimentary section on Broken Ridge consists of Turonian-middle Eocene limestone and chalk with volcanic ash, detrital sands and gravels associated with middle Eocene rifting and uplift, and a middle-late Oligocene unconformity overlain by a thin section of Neogene-Holocene pelagic calcareous ooze. The Turonian to Santonian ash-rich limestones accumulated at rates on the order of $2.5-5.0 \mathrm{~cm} / \mathrm{k} . \mathrm{y}$. Calcareous microfossils are rare or poorly preserved in these limestones which has resulted in less accurate age assignments for this section. Nannofossil stratigraphy indicates an age of Santonian for the highest Cretaceous sediments at Site 755 and foraminifer stratigraphy places the same interval in the Turonian-Coniacian, which lies entirely within the Cretaceous magnetic quiet zone, C34N.

The combined uppermost Cretaceous sections of Sites 752 and 754 are assigned to the Maestrichtian by calcareous nannofossil stratigraphy. Foraminifer data indicates that approximately the lower $250 \mathrm{~m}$ of Hole 754B belongs to the Campanian. Sedimentation rates calculated from the polarity data for the CampanianMaestrichtian are fairly high at around 5.0-6.0 cm/k.y.. Sedimentation rates drop to $\sim 1.0-1.2 \mathrm{~cm} / \mathrm{k} . \mathrm{y}$. for the uppermost Maestrichtian.

The Cretaceous/Tertiary boundary of Site 752 is located at the LO of Cretaceous planktonic foraminifers and an iridium peak at Sample 121-752B-11R-3, 94-95 cm. As expected, sedimentation rates drop further across the boundary as the calcium carbonate supply rapidly diminished. The rate through nannofossil Subzone CP1a of $0.93 \mathrm{~cm} / \mathrm{k}$.y. is lower than for surrounding intervals, however, not as low as most other deep-sea Cretaceous/Tertiary boundary sections due to a high volcanic ash accumulation. Conversely, an anomalously high sedimentation rate of $\sim 7.7 \mathrm{~cm} / \mathrm{k} . \mathrm{y}$. is calculated for initial Danian foraminifer Subzone P1a and is considered to be the result of the high degree of error associated with poor preservation and barren samples immediately above the Cretaceous/Tertiary boundary. Although the planktonic foraminifer and calcareous nannoplankton assemblages record a large drop in productivity across the Cretaceous/Tertiary boundary, benthic foraminifers are less affected and do not exhibit negative changes in production until later in the Danian.

The Paleocene to lower Eocene section at Site 752 is a remarkably thick continuous sequence containing abundant foraminifers and nannofossils as well as diatoms. Despite the high-latitude nature of assemblages, a fairly detailed stratigraphy has been obtained, augmented by excellent magnetic data. All nannofossil zones (CP1-CP10) can be identified with no apparent hiatuses. The foraminifer zonation is less detailed for the upper Paleocene and lower Eocene and several zones were necessarily combined. Foraminifer Zones P1-P12 are identified. The presence of abundant and well preserved diatoms in the middle Paleocene to lower Eocene section has resulted in a newly proposed diatom biozonation scheme that is well correlated with calcareous microfossil and magnetic stratigraphies.

Benthic foraminifers were divided into at least eight distinct assemblages, which indicate Paleocene deposition in middle to lower bathyal depths. The most dramatic change in benthic foraminifer assemblages is noted in uppermost Paleocene sediments of Site 752 within nannofossil Zone CP8. This event has been noted at a wide range of localities and is indicative of significant changes in bottom water composition and circulation (Miller et al., 1987; Thomas, 1989, 1990a, 1990b; Katz and Miller, 1990).

The thick, $\sim 240 \mathrm{~m}$, Paleocene-lower Eocene section at Site 752 was the result of fairly high sedimentation rates of $\sim 2.0$ $\mathrm{cm} / \mathrm{k}$.y. with the presence of abundant siliceous fossils indicative of high productivity for that time. In addition, a continuous but decreasing supply of volcanic ash through the Paleocene contributed to the higher sedimentation rates. Sedimentation rates apparently slowed by middle Eocene time as noted at Site 753 .

Last, the paleontologic and magnetostratigraphic data from Sites 752-755 support the scenario of rapid middle Eocene flexural uplift as a response to mechanical forces during rifting as opposed to thermally induced uplift. Uplift began during the middle Eocene (no later than Anomaly 18 time) with resubmergence of Broken Ridge commencing at least 4.0 m.y. later. Benthic foraminifers indicate that no shoaling of the plateau occurred preceding the rifting as would be expected if rifting occurred in response to thermal doming of the lithosphere. 


\section{ACKNOWLEDGMENTS}

The first author would like to thank all co-authors for their cooperation on this project. The suggestions by reviewers, S. W. Wise and L. H. Burckle helped improve the manuscript. Comments by J. Weissel and J. Peirce also greatly improved this paper.

\section{REFERENCES}

Banner, F. T., and Blow, W. H., 1965. Progress in the planktonic foraminiferal biostratigraphy of the Neogene. Nature, 208:1164-1166.

Berggren, W. A., Kent, D. V., Flynn, J. J., and Van Couvering, J. A., 1985. Cenozoic geochronology. Geol. Soc. Am. Bull., 96:1407-1418.

Berggren, W. A., and Miller, K. G., 1989. Cenozoic bathyal and abyssal calcareous benthic foraminiferal zonations. Micropaleontology, $35: 308-320$

Blow, W. H., 1969. Late middle Eocene to Recent planktonic biostratigraphy. In Brönnimann, P., and Renz, H. H. (Eds.), Proc. 1st Int. Conf. Planktonic Microfossils, Geneva, 1967. 1:199-421.

Caron, M., 1985. Cretaceous planktic foraminifera. In Bolli, H. M., Saunders, J. B., and Perch-Nielsen, K. (Eds.), Plankton Stratigraphy: Cambridge (Cambridge Univ. Press), 713-762.

Davies, T. A., Luyendyk, B. P., et al., 1974. Init. Repts., DSDP, 26: Washington (U.S. Govt. Printing Office).

Hsü, K. J., and MacKenzie, J. A., 1985. A "strangelove" ocean in the earliest Tertiary. In Sundquist, E. T., and Broecker, W. S. (Eds.), The Carbon Cycle and Atmospheric $\mathrm{CO}_{2}$ : Natural Variations Archean to Present. Am. Geophys. Union, 32:497-492.

Katz, M. E., and Miller, K. G., 1991. Early Paleogene benthic foraminiferal assemblages and stable isotopes in the Southern Ocean. In Ciesielski, P. F., Kristoffersen, Y., et al., Proc. ODP, Sci. Results, 114: College Station, TX (Ocean Drilling Program), 481-512.

Kent, D. V., and Gradstein, F. M., 1985. A Cretaceous and Jurassic geochronology. Geol. Soc. Am. Bull., 96:1419-1427.

Miller, K. G., Janecek, T. R., Katz, M. E., and Keil, D. J., 1987. Abyssal circulation and benthic foraminiferal changes near the Paleocene/Eocene boundary. Paleoceanography, 2:741-761.

Okada, H., and Bukry, D., 1980. Supplementary modification and introduction of code numbers to the low latitude coccolith biostratigraphic zonation (Bukry, 1973; 1975). Mar. Micropaleontol., 5:321-325.

Peirce, J. W., 1978. The northward motion of India since the Late Cretaceous. Geophys. J. R. Astron. Soc., 52:277-312.

Peirce, J., Weissel, J., et al., 1989. Proc. ODP, Init. Repts., 121: College Station, TX (Ocean Drilling Program).

Perch-Nielsen, K., 1985. Cenozoic calcareous nannofossils. In Bolli, H. M., Saunders, J. B., and Perch-Nielsen, K. (Eds.), Plankton Stratigraphy: Cambridge (Cambridge Univ. Press), 427-554.

Pospichal, J. J., and Wise, S. W., Jr., 1990. Paleocene to middle Eocene calcareous nannofossils of ODP Sites 689 and 690, Maud Rise, Wed- dell Sea. In Barker, P. F., Kennett, J. P., et al., Proc. ODP, Sci. Results, 113: College Station, TX (Ocean Drilling Program), 613-638.

Rea, D. K., Dehn, J., Driscoll, N., Farrell, J., Janecek, T., Owen, R. M., Pospichal, J. L., Resiwati, P., and the ODP Leg 121 Scientific Party, 1990. Paleoceanography of the Eastern Indian Ocean from ODP Leg 121 Drilling on Broken Ridge. Geol. Soc. Am. Bull., 102:679-690.

Royer, J.-Y., and Sandwell, D. T., 1989. Evolution of the eastern Indian Ocean since the late Cretaceous: constraints from GEOSAT altimetry. J. Geophys. Res., 94:13755-13782.

Sissingh, W., 1977. Biostratigraphy of Cretaceous calcareous nannoplankton. Geol. Mijnbouw, 56:37-65.

Smit, J., 1982. Extinction and evolution of planktonic foraminifera after a major impact at the Cretaceous/Tertiary boundary. In Silver, L. T., and Schultz, P. H. (Eds.), Spec. Pap.-Geol. Soc. Am., 190:329-352.

Thomas, E., 1989. Development of Cenozoic deep-sea benthic foraminiferal faunas in Antarctic waters. In Crame, J. A. (Ed.), Origins and Evolution of Antarctic Biota. Geol. Soc. Spec. Publ. London, 47:283-296.

1990a. Late Cretaceous through Neogene deep-sea benthic foraminifers (Maud Rise, Weddell Sea, Antarctica). In Barker, P. F., Kennett, J. P., et al., Proc. ODP, Sci. Results, 113: College Station, TX (Ocean Drilling Program), 571-594.

1990b. Mass extinctions in the deep sea. In Sharpton, V., and Ward, P. (Eds.), Proceedings of the Conference on Global Catastrophes in Earth History: An Interdisciplinary Conference on Impacts, Volcanism, and Mass Mortality. Spec. Pap. Geol. Soc. Am., 247:481-496.

Tjalsma, R. C., and Lohmann, G. P., 1983. Paleocene-Eocene bathyal and abyssal benthic foraminifera from the Atlantic Ocean. Micropaleontol. Spec. Publ., 4:1-90.

van Morkhoven, F.P.C.M., Berggren, W. A., and Edwards, A. S., 1986. Cenozoic cosmopolitan deep-water benthic foraminifera. Bull. Cent. Rech. Explor.-Prod. Elf-Aquitaine, Mem. 11.

Weissel, J. K., et al., 1988. Tectonic history of Broken Ridge from ODP 121 drilling and marine geophysical data. Eos, 69:1431-1432. (Abstract)

Weissel, J. K., and Karner, G. D., 1989. Flexural uplift of rift flanks due to mechanical unloading of the lithosphere during extension. J. Geophys. Res., 94:13919-13950.

Zachos, J. C., Arthur, M. A., and Dean, W. E., 1989. Geochemical evidence for suppression of pelagic marine productivity at the Cretaceous-Tertiary boundary. Nature, 337:61-64.

Date of initial receipt: 12 September 1990

Date of acceptance: 6 December 1990

Ms 121B-181 